\title{
The Historic Caddo Component at the Roseborough Lake Site (41BW5) on the Red River in Bowie County, Texas
}

Timothy K. Perttula

Heritage Research Center, Stephen F. Austin State University

Follow this and additional works at: https://scholarworks.sfasu.edu/ita

Part of the American Material Culture Commons, Archaeological Anthropology Commons, Environmental Studies Commons, Other American Studies Commons, Other Arts and Humanities Commons, Other History of Art, Architecture, and Archaeology Commons, and the United States History Commons

Tell us how this article helped you.

This Article is brought to you for free and open access by the Center for Regional Heritage Research at SFA ScholarWorks. It has been accepted for inclusion in Index of Texas Archaeology: Open Access Gray Literature from the Lone Star State by an authorized editor of SFA ScholarWorks. For more information, please contact cdsscholarworks@sfasu.edu. 


\section{The Historic Caddo Component at the Roseborough Lake Site (41BW5) on the Red River in Bowie County, Texas}

\section{Creative Commons License}

\section{(c) (1) \&}

This work is licensed under a Creative Commons Attribution-NonCommercial 4.0 International License 


\title{
The Historic Caddo Component at the Roseborough Lake Site (41BW5) on the Red River in Bowie County, Texas
}

\author{
Timothy K. Perttula
}

\section{Introduction}

The Roseborough Lake site (41BW5) is on an old meander of the Red River "that was cut off in 1872 and named Roseborough Lake" (Gilmore 1986:1). It lies a few miles west of other important Late Caddo and Historic Caddo period sites, and a few miles west of Texarkana in Bowie County (Figure 1).

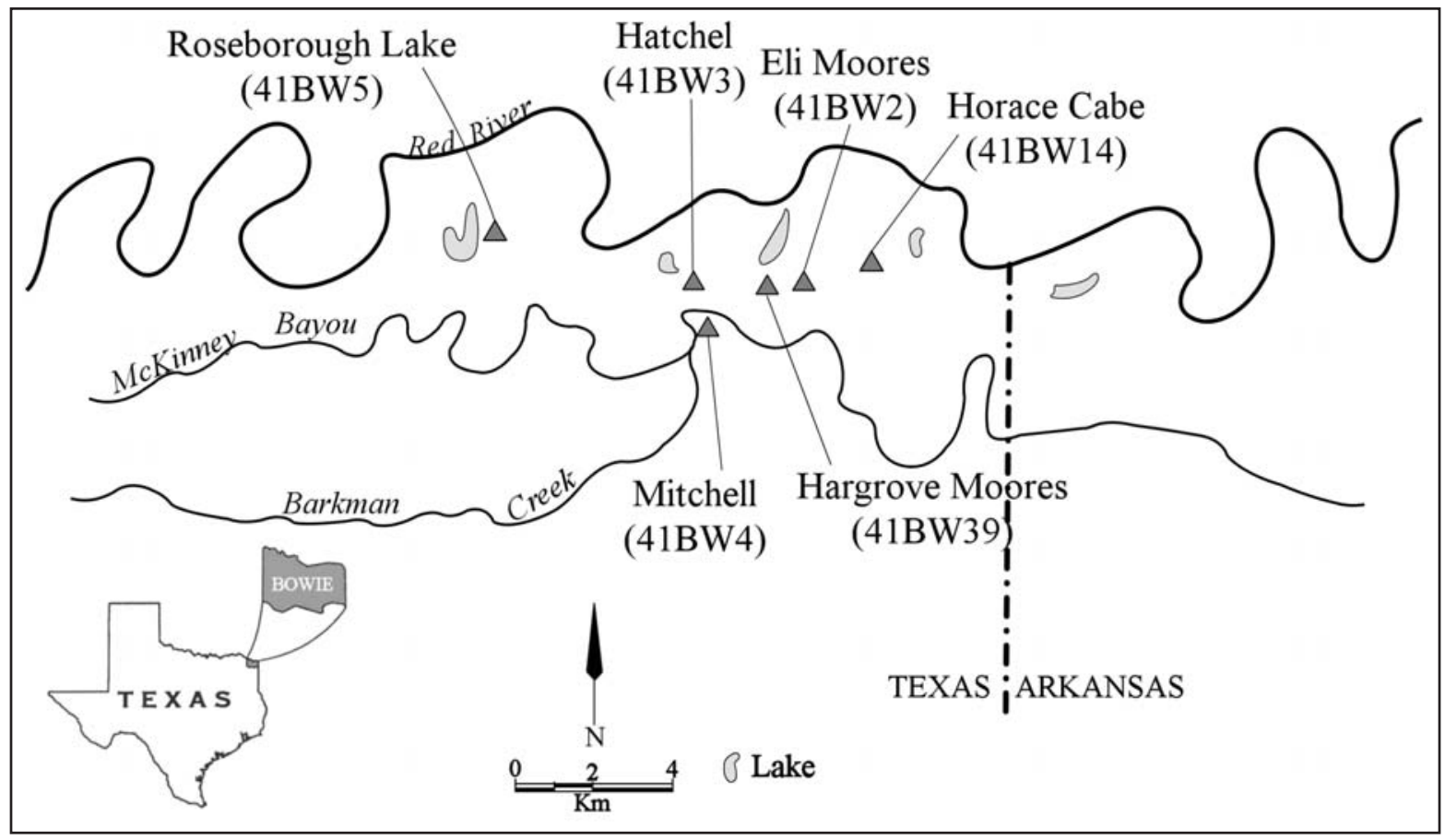

Figure 1. The Roseborough Lake site and other Caddo sites along the Red River in Bowie County, Texas.

The Roseborough Lake site is a large historic Caddo village occupied from the late $17^{\text {th }}$ century until the late $18^{\text {th }}$ century, with habitation features and cemeteries (Miroir et al. 1973: Gilmore 1986; Perttula 2014a). It also is the location of a Nassonite post established by the French in the 1720s, known by the Spanish as San Luis de Cadohadacho. In this article I focus on the analysis of the historic Caddo archaeological material remains, in particular the Caddo ceramic vessel sherds, from the Roseborough Lake site in the Lawrence Head collection. These material remains were collected almost exclusively in 1990 and 1991 after a natural flood of the site by the Red River and then later in 1991 after the machineleveling (Figure 2) of much of the site area for bean cultivation. 


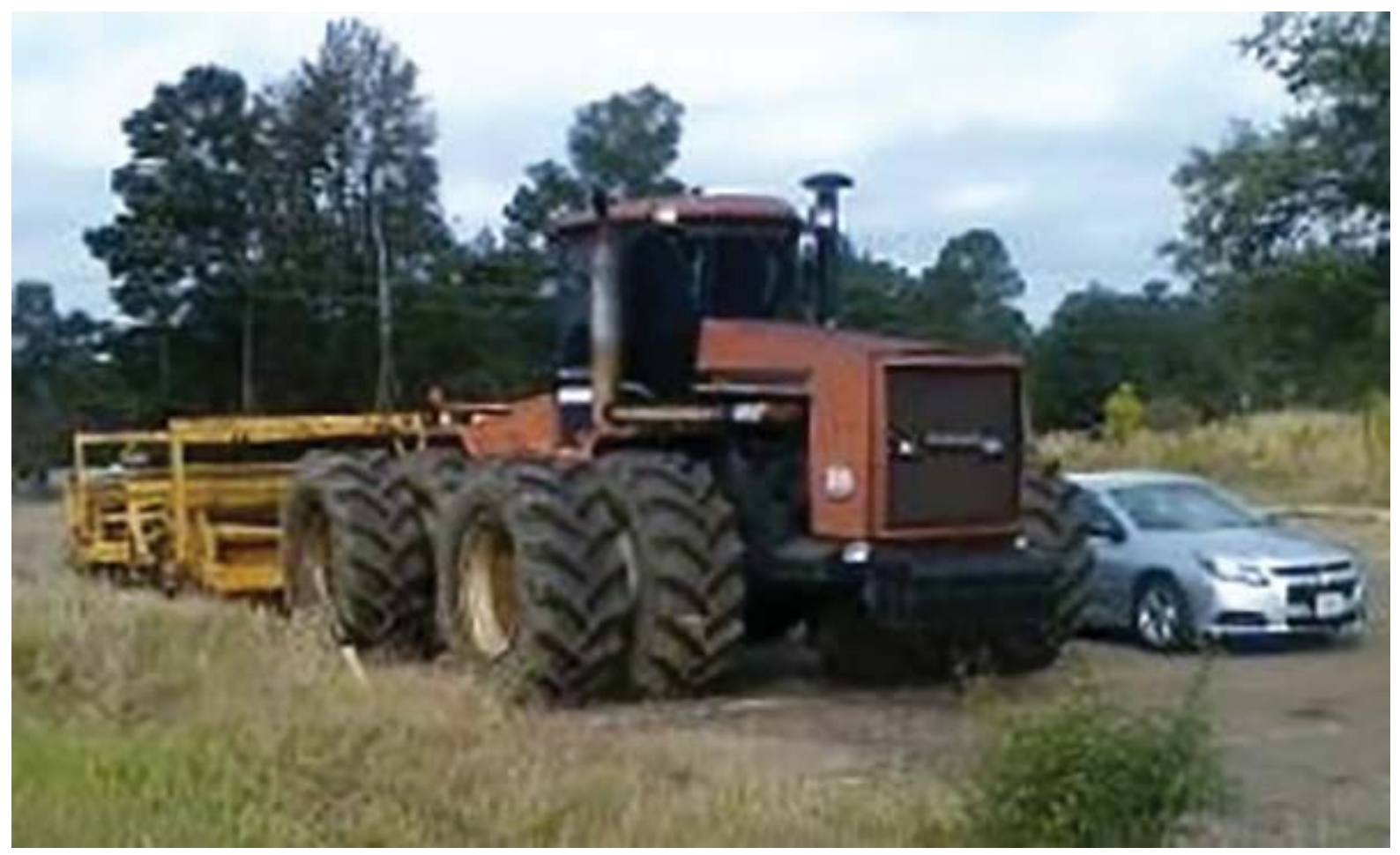

Figure 2. Type of machinery used to level the Roseborough Lake site. October 2016 Photograph courtesy of Lawrence Head.

\section{Earlier Miroir et al. and Gilmore Investigations}

The Miroir et al. (1973) investigations at the Roseborough Lake site took place at the southern end of the ca. $800 \mathrm{~m}$ long natural levee landform (Figure 3). In their work they encountered and identified eight occupational features (Features 1-8) and two Historic Caddo period burials at the southern end of the site/landform. The occupational features likely include midden deposits and the locations of Historic Caddo house deposits (Miroir et al. 1973:115).

Both burials were those of adults placed in an extended supine position, with their heads generally facing to the west and the House of Death (see Miroir et al. 1973:Figures 3-4). Both individuals had numerous funerary offerings. Burial 1 had nine ceramic vessels, including bottles $(n=1)$, carinated bowls $(n=5)$, bowls $(n=2)$, and jars $(n=1)$ of the types Natchitoches Engraved, Ebarb Incised, Simms Engraved, and Womack Engraved, as well as 1028 glass beads. Burial 2 had three ceramic vessels, among them a Simms Engraved vessel of unknown form and two small undecorated shell-tempered jars, probably McKinney Plain. Also placed in the grave were 30 conch shell beads, 48 blue glass beads, a ceramic pendant (see Miroir et al. 1973:Figure 4a) and six mussel shell spoons.

Gilmore's work at the Roseborough Lake site was done in 1976 as a North Texas State University (now University of North Texas) field school. Her excavations were also done in the southern part of the site (Figure 4), in the vicinity of the features and burials investigated earlier by Miroir et al. (1973). Unit 1 is in the area of the 1827-1841 Collin McKinney farm, and a brick chimney feature was encountered there. Excavations in other areas of the site identified $18^{\text {th }}$ century archaeological deposits, including midden deposits in Unit 7 and Caddo habitation areas in Units 2-4 and 6A-6C.

Investigations at the Roseborough Lake site by Miroir et al. (1973) and Gilmore (1986) recovered Historic Caddo ceramics, mainly shell-tempered, of the types Emory Punctated-Incised, McKinney Plain, 


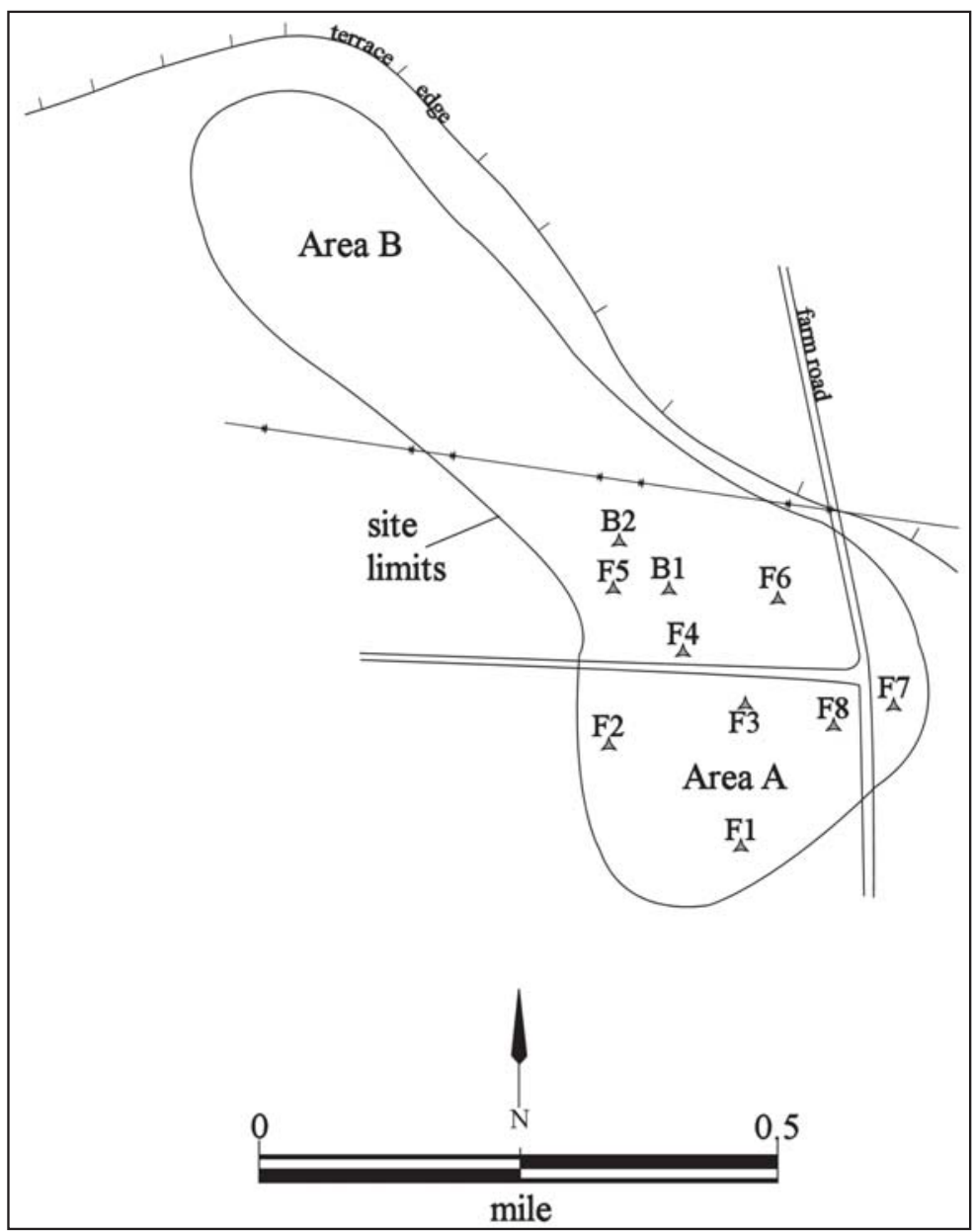

Figure 3. Miroir et al. (1973) map of the Roseborough Lake site.

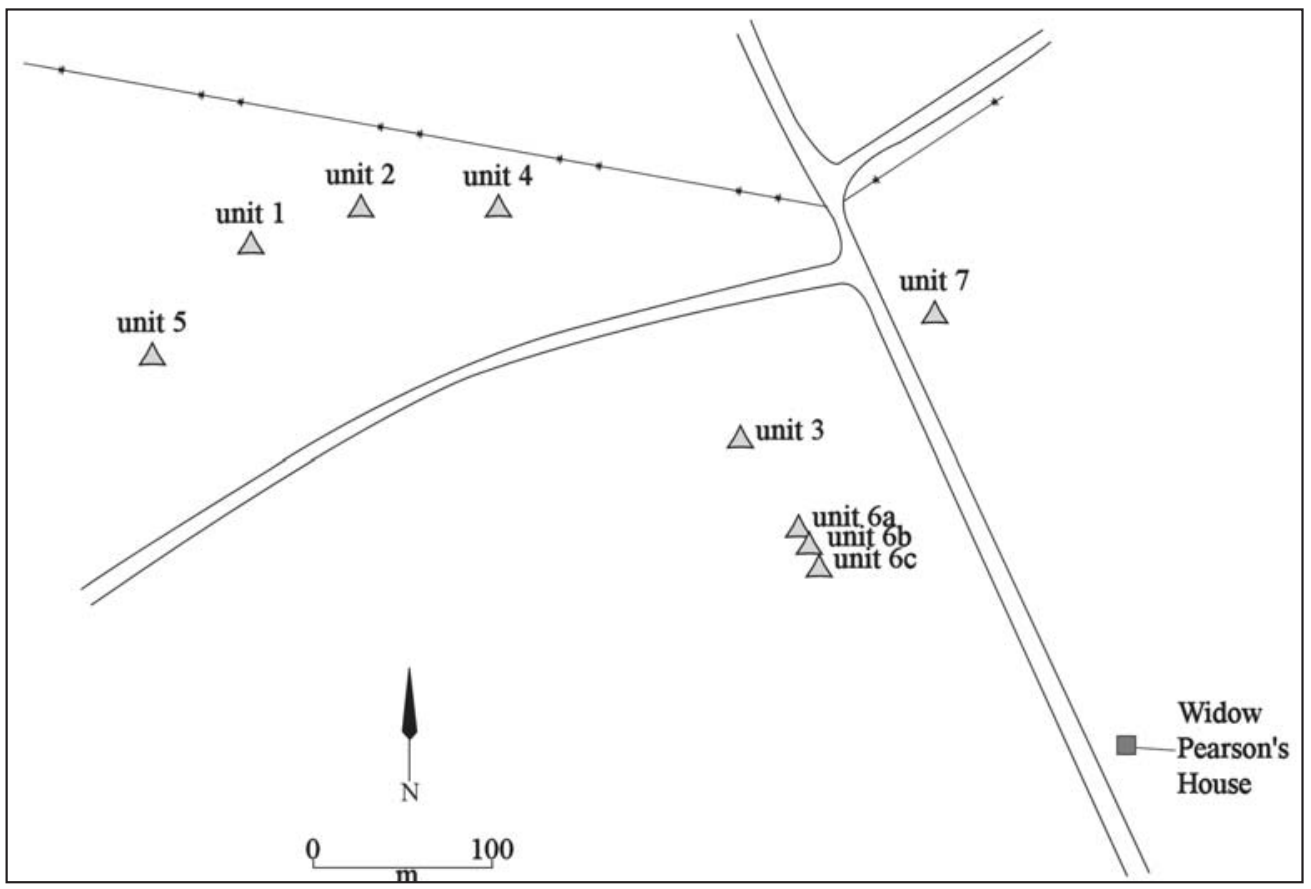

Figure 4. Map of the areas investigated by Gilmore (1986) in the southern part of the Roseborough Lake site. 
Keno Trailed, Simms Engraved, Natchitoches Engraved, Womack Engraved, and Avery Engraved, along with brushed, incised, punctated, and red-slipped body sherds and clay figurines and pipes. The chipped stone tool assemblage included Fresno and Maud arrow points, drills, large knives, many end/side scrapers, as well as a diorite celt. European trade goods are particularly abundant at the Roseborough Lake site, and they include iron axes and scrapers, iron bridle bits and knives, iron strike-a-lights, scissors, iron kettle pieces, pendants, many flintlock gun parts, gunflints, lead balls, brass rings, tinklers, bells, and rivets, brass and iron arrow points, metal buttons, green wine bottle glass and mirror glass, faience, majolica, and delft ceramics, along with many glass beads $(n=2958)$ and shell beads $(n=18)$. Substantial samples of animal bones are also present in the archaeological deposits at the site, along with carbonized maize cob fragments (Gilmore 1986:105-134).

\section{Lawrence Head Collection from the Roseborough Lake Site}

The 1990-1991 Lawrence Head collections from the Roseborough Lake site are surface collections done after flooding and land leveling in the southern part of the site (Figure 5). Areas where surface collections were obtained include the early $19^{\text {th }}$ century Collin McKinney component, leveled "new ground" east of that component, and in an trapezoid-shaped area around the locations of Gilmore's Units 3, 6A-6C; this was the Head main collection area, and several disturbed burials were noted here. Other possible burial features were noted up to $200 \mathrm{~m}$ west of Head's main collection area (see Figure 5).

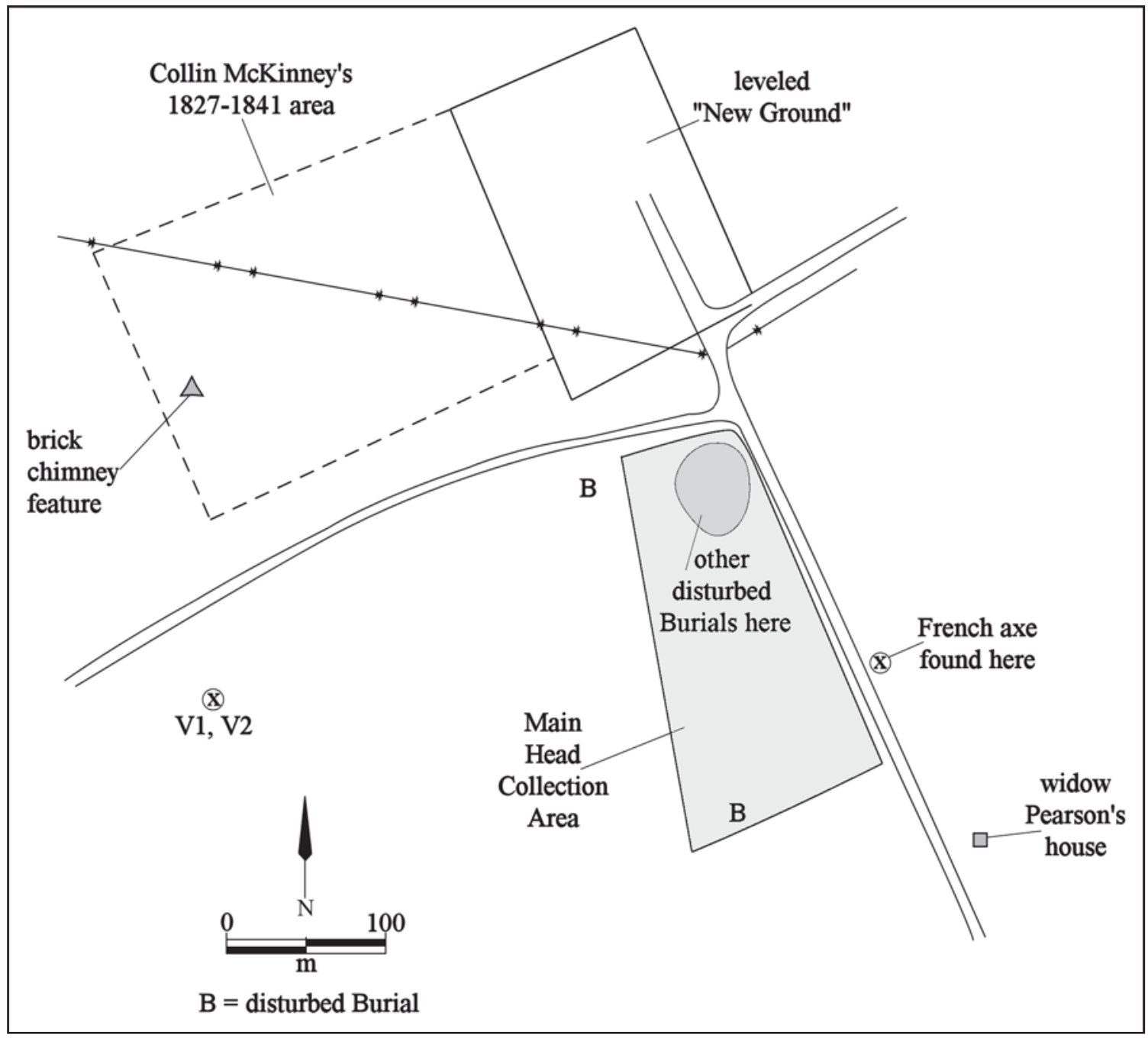

Figure 5. Map of the Lawrence Head collection areas at the Roseborough Lake site. 


\section{Ceramic Artifacts}

\section{Ceramic Vessel Sections}

The Head collection has remnants of three different Caddo ceramic vessels or vessel sections. Two were recovered in the western portion of Head's collection area (Vessels 1 and 2), and the third is associated with Burial 4 in the main collection area (see Figure 5).

SITE NAME OR SITE NUMBER: Roseborough Lake (41BW5)

VESSEL NO.: 1 (Head collection)

VESSEL FORM: Bowl

NON-PLASTICS AND PASTE: shell-tempered

RIM AND LIP FORM: N/A

CORE COLOR: $\mathrm{H}$ (fired in a reducing environment and cooled in the open air)

INTERIOR SURFACE COLOR: brown

EXTERIOR SURFACE COLOR: very dark gray

WALL THICKNESS (IN MM): body, $5.6 \mathrm{~mm}$; base, $9.4 \mathrm{~mm}$

INTERIOR SURFACE TREATMENT: smoothed

EXTERIOR SURFACE TREATMENT: smoothed on the base

HEIGHT (IN CM): N/A

ORIFICE DIAMETER (IN CM): N/A

DIAMETER AT BOTTOM OF RIM OR NECK (IN CM): N/A

BASE DIAMETER (IN CM) AND SHAPE OF BASE:

N/A, flat base

ESTIMATED VOLUME (IN LITERS): N/A

DECORATION (INCLUDING MOTIF AND ELEMENTS

WHEN APPARENT): The upper part of the vessel has a series of diagonal and curvilinear incised lines around a circular appliqued node (Figure 6).

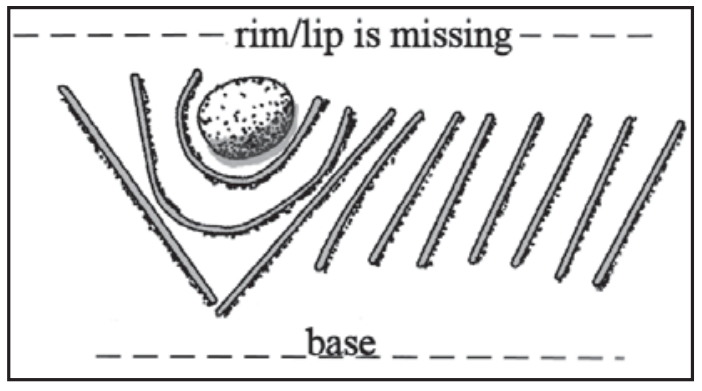

Figure 6. Vessel 1, decorative elements on incised-appliqued bowl vessel section from the Head collection from the Roseborough Lake site.

TYPE AND VARIETY (IF KNOWN): Unidentified utility ware vessel, perhaps Foster Trailed-Incised 
SITE NAME OR SITE NUMBER: Roseborough Lake site (41BW5)

VESSEL NO.: 2 (Head collection)

VESSEL FORM: Jar

NON-PLASTICS AND PASTE: shell-tempered

RIM AND LIP FORM: N/A

CORE COLOR: $\mathrm{H}$ (fired in a reducing environment and cooled in the open air)

INTERIOR SURFACE COLOR: brown

EXTERIOR SURFACE COLOR: very dark grayish-brown

WALL THICKNESS (IN MM): lower rim, $4.9 \mathrm{~mm}$; body, $6.2 \mathrm{~mm}$; base, $8.5 \mathrm{~mm}$

INTERIOR SURFACE TREATMENT: none

EXTERIOR SURFACE TREATMENT: smoothed on the base

HEIGHT (IN CM): 11.0+

ORIFICE DIAMETER (IN CM): 13.0

DIAMETER AT BOTTOM OF RIM OR NECK (IN CM): N/A

BASE DIAMETER (IN CM) AND SHAPE OF BASE: $5.5 \mathrm{~cm}$; circular and flat

ESTIMATED VOLUME (IN LITERS): 0.86+

DECORATION (INCLUDING MOTIF AND ELEMENTS WHEN APPARENT): The lower portion of the rim has two horizontal rows of tool punctations. The vessel body has a series of vertical incised panels (defined by two sets of closely-spaced vertical incised lines) filled with sets of diagonal opposed incised lines (Figure 7). The panels extend from the rim-body juncture to near the vessel base.

PIGMENT USE AND LOCATION ON VESSEL: none

TYPE AND VARIETY (IF KNOWN): Emory Punctated-Incised

The third vessel section is comprised of seven rim sherds, 11 body sherds, and two base sherds from a shell-tempered Natchitoches Engraved bowl associated with Burial 4 (Figure 8a-b). The rim has slanting scrolls with downward-pointing excised tick marks and upper and lower triangular scroll fill zones with negative oval elements. There is an elevated narrow horizontal ridge separating the rim from the decorative elements on the vessel body. The engraved elements on the vessel body include curvilinear scroll lines (with excised tick marks) that end in hooked arms with curvilinear zones above and below divided into negative oval areas. 


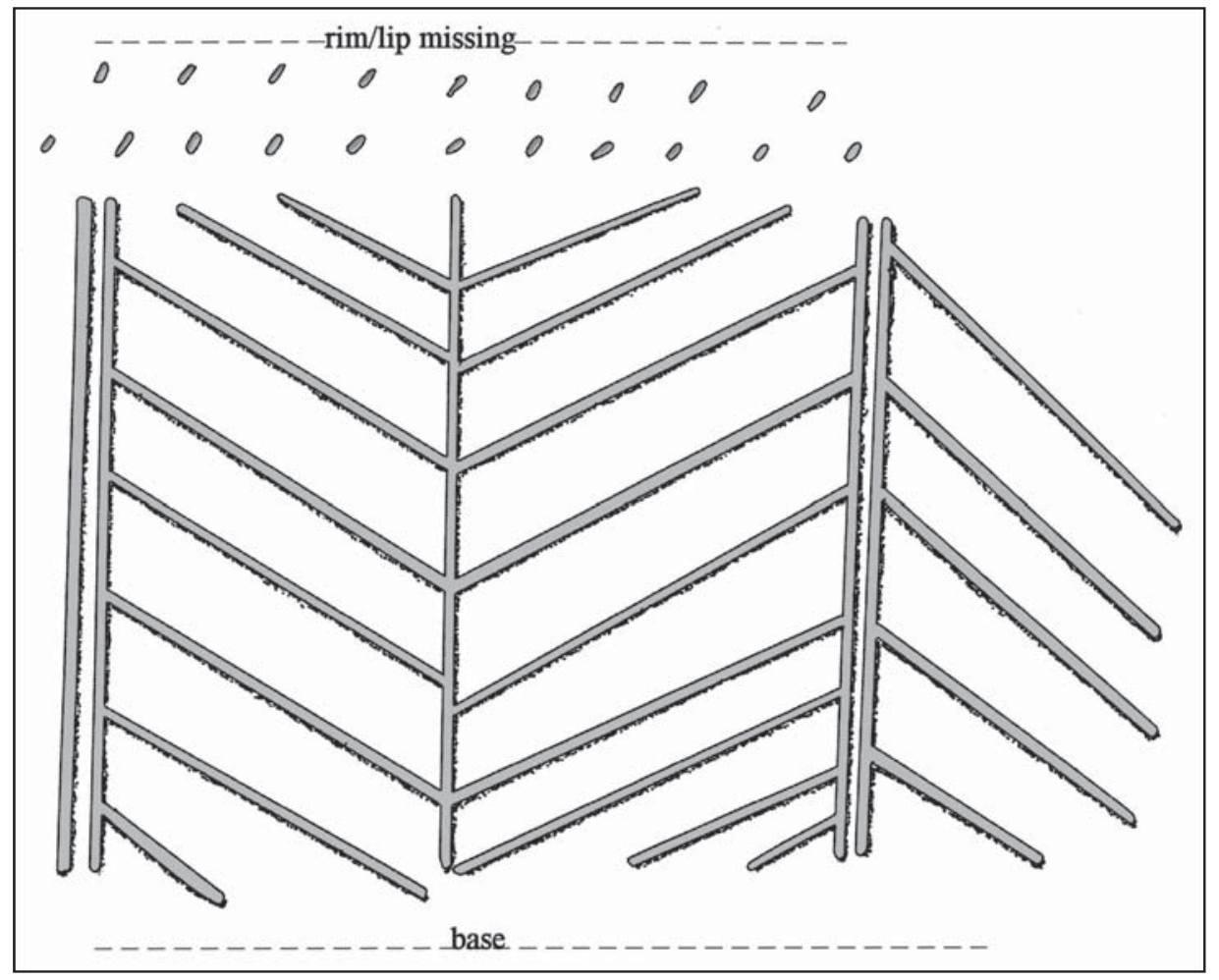

Figure 7. Vessel 2, decorative elements on Emory Punctated-Incised jar vessel section in the Head collection from the Roseborough Lake site.

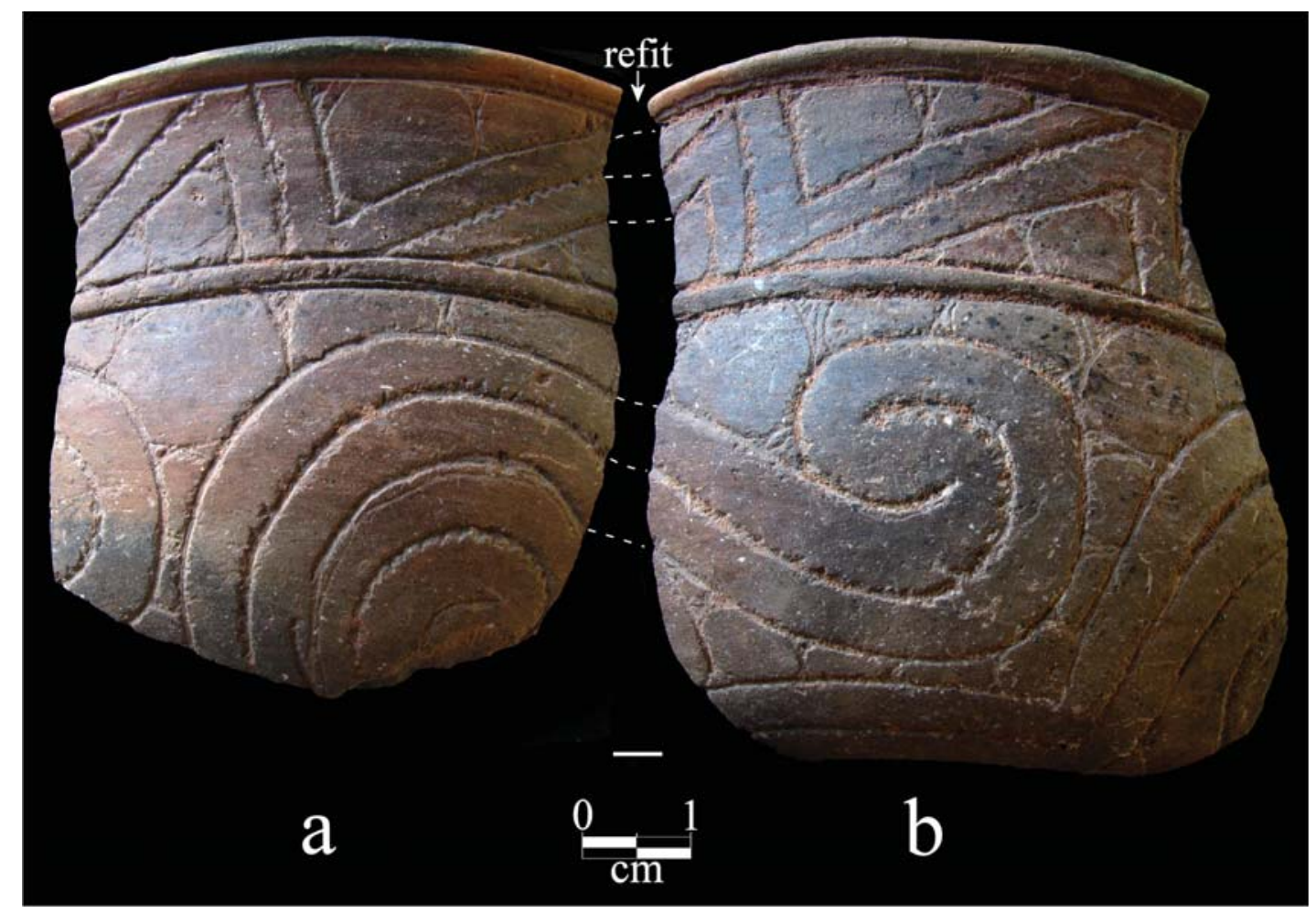

Figure 8. Natchitoches Engraved bowl from Burial 4 in the Head collection: a-b, photographs of vessel sections. 


\section{Ceramic Vessel Sherds}

The Head collection from the Roseborough Lake site includes 3692 ceramic vessel sherds comprised of 2686 plain rim, body, and base sherds as well as 1006 rim and body sherds with decorative elements. These sherds are from shell-tempered, grog-tempered, grog-bone-tempered, and bone-tempered vessels (Table 1). The largest proportion of sherds are from either grog-tempered (49.5 percent) or shelltempered (45.0 percent) vessels, with only a few sherds from grog-bone-tempered (3.6 percent) or bonetempered (1.9 percent) vessels. Of the decorated sherds, 60 percent are from utility wares, and most of these are from shell- and grog-tempered vessels. Utility ware sherds are proportionally well represented in the shell-, grog-bone-, and bone-tempered vessel sherds, while fine wares are best represented in the grog-tempered vessel sherds.

Table 1. Ceramic vessel sherds in the Head collection from the Roseborough Lake site.

\begin{tabular}{llllll}
\hline Ware & $\begin{array}{l}\text { Shell- } \\
\text { tempered }\end{array}$ & $\begin{array}{l}\text { Grog- } \\
\text { tempered }\end{array}$ & $\begin{array}{l}\text { Grog-bone- } \\
\text { tempered }\end{array}$ & $\begin{array}{l}\text { Bone- } \\
\text { tempered }\end{array}$ & N \\
\hline Plain & 1229 & 1298 & 105 & 54 & 2686 \\
Utility & 312 & 260 & 23 & 12 & 607 \\
Fine & 121 & 269 & 7 & 2 & 399 \\
\hline Totals & 1662 & 1827 & 135 & 68 & 3692 \\
\hline
\end{tabular}

Combining the Head collection with the ceramic assemblages from the Miroir et al. (1973) and Gilmore (1986) investigations, the total assemblage of 6579 sherds from the Roseborough Lake site has 4708 plain ware sherds and 1871 sherds from decorated utility ware and fine ware sherds (Table 2). The plain to decorated sherd ratio in the combined assemblage is 2.52. Shell-tempered sherds amount to 57 percent of the combined assemblages, followed by 38 percent of the sherds being from grogtempered vessels. Utility ware sherds represent 57 percent of the decorated sherds, with the remainder of the decorated sherds coming from fine ware vessels. Again, utility ware sherds are best represented in the shell-tempered, grog-bone-tempered, and bone-tempered wares, while fine ware sherds are best represented in the grog-tempered vessels.

Table 2. Ceramic vessel sherds from different reported investigations at the Roseborough Lake site.

\begin{tabular}{llllll}
\hline Ware & $\begin{array}{l}\text { Shell- } \\
\text { tempered }\end{array}$ & $\begin{array}{l}\text { Grog- } \\
\text { tempered }\end{array}$ & $\begin{array}{l}\text { Grog-bone- } \\
\text { tempered }\end{array}$ & $\begin{array}{l}\text { Bone- } \\
\text { tempered }\end{array}$ & $\mathrm{N}$ \\
\hline Plain & 2706 & 1751 & 105 & 146 & 4708 \\
Utility & 670 & 332 & 23 & 38 & 1063 \\
Fine & 363 & 431 & 9 & 5 & 808 \\
\hline Totals & 3739 & 2514 & 137 & 189 & $6579^{*}$ \\
\hline
\end{tabular}

*does not include 12 sandy paste sherds identified in Gilmore (1986)

The 1871 decorated sherds in Table 2 can be divided into a number of decorative methods among the utility ware and fine ware vessels (Table 3 ). More than 85 percent of the utility ware sherds have incised decorative elements, and these are likely all from Emory Punctated-Incised vessels. The punctated sherds (7.9 percent of the utility wares) are likely also from Emory Punctated-Incised vessels, as are the few 
incised-punctated sherds. The brushed, brushed-incised, and brushed-punctated sherds (representing a combined 8.3 percent of the utility wares) are from Karnack Brushed-Incised vessels. A few sherds (0.9 percent) have appliqued decorative elements, the neck banded sherds are from Nash Neck Banded jars, and four sherds are from lip notched vessels.

Table 3. Decorated ceramic vessel sherds from utility ware and fine ware vessels from different reported investigations at the Roseborough Lake site.

\begin{tabular}{lllll}
\hline Decorative method & $\begin{array}{l}\text { Head } \\
\text { Collection }\end{array}$ & $\begin{array}{l}\text { Miroir et al. } \\
(1973)\end{array}$ & $\begin{array}{l}\text { Gilmore } \\
(1986)\end{array}$ & $\mathrm{N}$ \\
\hline
\end{tabular}

Utility ware

\begin{tabular}{lllll} 
Appliqued & 8 & - & - & 8 \\
Appliqued-Punctated & 1 & - & - & 1 \\
Brushed & 60 & 6 & 5 & 71 \\
Brushed-Incised & 10 & - & - & 10 \\
Brushed-Punctated & 3 & - & - & 3 \\
Incised & 417 & 224 & 210 & 851 \\
Incised-Lip Notched & 1 & - & - & 1 \\
Incised-Punctated & 4 & - & - & 4 \\
Lip Notched & 2 & - & - & 2 \\
Neck Banded & 4 & - & - & 4 \\
Neck Banded-Incised & 1 & - & - & 1 \\
Punctated & 66 & 11 & 2 & 79 \\
Punctated-Lip Notched & 1 & - & - & 29 \\
Trailed (Foster) & 29 & - & - & \\
& & & & 728 \\
Fine ware & & 189 & 190 & 35 \\
Engraved & 349 & 13 & - & 43 \\
Red-slipped & 22 & 14 & & 1871 \\
Trailed & 28 & 457 & 408 & \\
\hline Totals & 1006 & & & \\
\hline
\end{tabular}

The fine ware sherds are predominantly from engraved vessels (86 percent), including those of the Natchitoches Engraved, Simms Engraved, and Hodges Engraved types (see Table 3). About 4 percent of the fine ware sherds have a hematite-rich red slip on either one or both vessel surfaces, and 5 percent are from Keno Trailed vessels. More specific details on the decorative methods and elements in the utility ware and fine ware vessel sherds are provided by temper categories in Tables 4-7, as discussed below.

The utility ware sherds from shell-tempered vessels in the Head collection from the Roseborough Lake site are dominated by sherds with incised decorative elements. Incised sherds comprise more than 81 percent of the utility wares (Table 4). Brushed (5.8 percent, as well as brushed-incised, 1.6 percent, and brushed-punctated, 0.3 percent) and punctated (5.4 percent) decorative elements are uncommon by comparison. Other utility wares that are from shell-tempered vessels include those with appliqued nodes (1.0 percent, probably on Emory Punctated-Incised vessels), incised-punctated (1.0 percent), lip notched ( 0.3 percent), neck banded (0.6 percent), and Foster Trailed-Incised, var. unspecified sherds (2.6 percent). 
Table 4. Decorative elements in the shell-tempered vessel sherds in the Head collection from the Roseborough Lake site.

\begin{tabular}{llll}
\hline Decorative method and element & Rim & Body & N \\
\hline
\end{tabular}

\section{Utility ware}

Appliqued

circular appliqued node

\section{Brushed}

curvilinear brushed

horizontal brushed

opposed brushed

overlapping brushed

parallel brushed

parallel brushed in zones

parallel-curvilinear brushed

vertical brushed

Brushed-Incised

parallel brushed-incised marks and lines

parallel brushed and overlying opposed incised lines

parallel brushed and overlying straight incised line

\section{Brushed-Punctated}

diagonal brushed-tool punctated rows

-
-
-
-
-
-
-
-

\section{Incised}

circular incised el.

cross-hatched incised lines

curvilinear incised lines

curvilinear and straight incised lines

diagonal incised lines

diagonal opposed incised lines

diagonal-vertical incised lines

diagonal incised lines and cross-hatched zone

$1+$ horizontal incised line

horizontal and diagonal incised lines

opposed incised lines

parallel incised lines

parallel-curvilinear incised lines

parallel-diagonal incised lines

straight incised line

straight and curvilinear incised lines

straight-diagonal incised lines

vertical and diagonal opposed incised lines

(Emory Punctated-Incised)

\section{Incised-Punctated}

diagonal incised line and tool punctated rows straight incised line-single linear tool punctate tool punctated rows above diagonal incised lines

$\begin{array}{lll}- & 1 & 1 \\ - & 3 & 3 \\ - & 1 & 1\end{array}$


Table 4. Decorative elements in the shell-tempered vessel sherds in the Head collection from the Roseborough Lake site, cont.

\begin{tabular}{llll}
\hline Decorative method and element & Rim & Body & N \\
\hline $\begin{array}{l}\text { Lip Notched } \\
\text { lip notched }\end{array}$ & 1 & - & 1 \\
Neck Banded & & & 1 \\
parallel neck bands & - & 1 & \\
Neck Banded-Incised & & & 1 \\
horizontal neck bands-diagonal incised lines & 1 & - & 1 \\
$\begin{array}{l}\text { Punctated } \\
\text { fingernail punctated rows }\end{array}$ & & & 2 \\
linear tool punctated row & - & 1 & 2 \\
single tool punctate & - & 2 & 12 \\
tool punctated rows & - & 2 & \\
Trailed & 2 & 10 & 2 \\
curvilinear trailed lines (Foster Trailed-Incised) \\
parallel trailed lines (Foster Trailed Incised) \\
straight trailed line (Foster Trailed-Incised)
\end{tabular}

\section{Fine ware}

\section{Engraved}

bracket-shaped hatched engraved zone

circular engraved el. and diagonal opposed

engraved lines

circular engraved el. and horizontal-curvilinear

and diagonal engraved lines

circular engraved line with tick marks and

hatched triangle el. (Natchitoches Engraved)

cross-hatched engraved bracket el.

cross-hatched engraved zone

cross-hatched zone with negative ovals and

curvilinear engraved line with tick marks

(Natchitoches Engraved)

cross-hatched engraved triangle el.

cross-hatched engraved zone and parallel engraved lines

cross-hatched and curvilinear hatched zones

and negative ovals (Natchitoches Engraved)

curvilinear hatched engraved zone

curvilinear cross-hatched zone (Natchitoches Engraved)

curvilinear engraved zone with diagonal opposed

engraved lines

curvilinear engraved lines

curvilinear engraved lines that end in hooked

arm el. (Natchitoches Engraved)

curvilinear engraved lines with tick marks

$\begin{array}{lll}- & 1 & 1 \\ 1 & - & 1 \\ 1 & - & 1 \\ - & 1 & 1 \\ & & \\ 1 & - & 1 \\ - & 13 & 13 \\ - & 1 & 1 \\ & & \\ & & 1 \\ - & 1 & 1 \\ - & 1 & 1 \\ - & 1 & 3 \\ - & 3 & 5 \\ - & 5 & 1 \\ - & 1 & 8 \\ - & 8 & 1 \\ - & 1 & 5\end{array}$


Table 4. Decorative elements in the shell-tempered vessel sherds in the Head collection from the Roseborough Lake site, cont.

\begin{tabular}{|c|c|c|c|}
\hline Decorative method and element & Rim & Body & $\mathrm{N}$ \\
\hline $\begin{array}{l}\text { curvilinear engraved line with tick marks and } \\
\text { cross-hatched engraved bracket el. }\end{array}$ & - & 1 & 1 \\
\hline $\begin{array}{l}\text { curvilinear engraved line with tick marks and } \\
\text { narrow hatched zone (Natchitoches Engraved) }\end{array}$ & - & 1 & 1 \\
\hline $\begin{array}{l}\text { curvilinear engraved line with tick marks and } \\
\text { triangular hatched zone (Natchitoches Engraved) }\end{array}$ & - & 1 & 1 \\
\hline curvilinear opposed engraved lines & - & 1 & 1 \\
\hline $\begin{array}{l}\text { diagonal engraved line with tick marks and } \\
\text { cross-hatched negative oval el. (Natchitoches Engraved) }\end{array}$ & 1 & - & 1 \\
\hline diagonal hatched scroll zone & - & 1 & 1 \\
\hline diagonal opposed engraved lines & - & 1 & 1 \\
\hline 1+ horizontal engraved line & 4 & 2 & 6 \\
\hline horizontal engraved line and horizontal cross-hatched zone & 1 & - & 1 \\
\hline horizontal engraved lines with tick marks (Simms Engraved) & 2 & 1 & 3 \\
\hline $\begin{array}{l}\text { horizontal engraved lines with tick marks and } \\
\text { cross-hatched bracket el. (Natchitoches Engraved) }\end{array}$ & - & 2 & 2 \\
\hline $\begin{array}{l}\text { horizontal engraved lines with tick marks and } \\
\text { curvilinear engraved lines (Natchitoches Engraved) }\end{array}$ & - & 1 & 1 \\
\hline $\begin{array}{l}\text { horizontal engraved line with tick marks and } \\
\text { vertical hatched zone (Natchitoches Engraved) }\end{array}$ & 1 & - & 1 \\
\hline $\begin{array}{l}\text { horizontal engraved line and curvilinear lines with } \\
\text { tick marks (Natchitoches Engraved) }\end{array}$ & - & 1 & 1 \\
\hline $\begin{array}{l}\text { horizontal engraved lines and curvilinear lines } \\
\text { that end in hooked arms (Natchitoches Engraved) }\end{array}$ & - & 1 & 1 \\
\hline horizontal engraved line and hatched pendant triangles & 1 & - & 1 \\
\hline horizontal-vertical engraved lines & 1 & 1 & 2 \\
\hline narrow hatched engraved zone & - & 1 & 1 \\
\hline opposed engraved lines & - & 3 & 3 \\
\hline parallel engraved lines & - & 8 & 8 \\
\hline parallel engraved lines with tick marks & - & 5 & 5 \\
\hline parallel and curvilinear engraved lines with tick marks & - & 1 & 1 \\
\hline parallel and diagonal engraved lines & - & 1 & 1 \\
\hline straight engraved line with tick marks & - & 2 & 2 \\
\hline straight engraved line & - & 11 & 11 \\
\hline straight and diagonal engraved lines & - & 1 & 1 \\
\hline triangular hatched zone & - & 4 & 4 \\
\hline \multicolumn{4}{|l|}{ Engraved-Incised } \\
\hline \multicolumn{4}{|l|}{ Red-Slipped } \\
\hline ext. red-slipped & - & 1 & \\
\hline \multicolumn{4}{|l|}{ Trailed } \\
\hline curvilinear trailed lines (Keno Trailed) & - & 6 & 6 \\
\hline opposed curvilinear trailed lines (Keno Trailed) & - & 1 & 1 \\
\hline parallel trailed lines (Keno Trailed) & - & 1 & 1 \\
\hline straight trailed line (Keno Trailed) & - & 1 & 1 \\
\hline Sub-total, fine wares & 14 & 107 & 121 \\
\hline Totals & 23 & 410 & 433 \\
\hline
\end{tabular}


The majority of the shell-tempered incised utility ware sherds have simple geometric elements, including straight, parallel, diagonal, diagonal opposed, and vertical-diagonal opposed lines (Figure 9a-d). These are from Ebarb Incised (Figure 9a, c-d) and Emory Punctated-Incised (Figure 9b) vessels, including bowls and jars (Gregory and Avery 2007:45-48; Story et al. 1967:136-137 and Figure 57gi). On Ebarb Incised vessels, the incised decorative elements are confined to the rim, but on Emory Punctated-Incised jars, the incising is on the bodies, and "consists of straight to slightly curved lines extending from below the rim to the base or to about the middle of the body" (Story et al. 1967:137; see also Gregory and Avery 2007:55-58). The one shell-tempered incised-punctated body sherd is likely also from an Emory Punctated-Incised vessel, as are the various fingernail and tool punctated rim and body sherds (see Table 4).

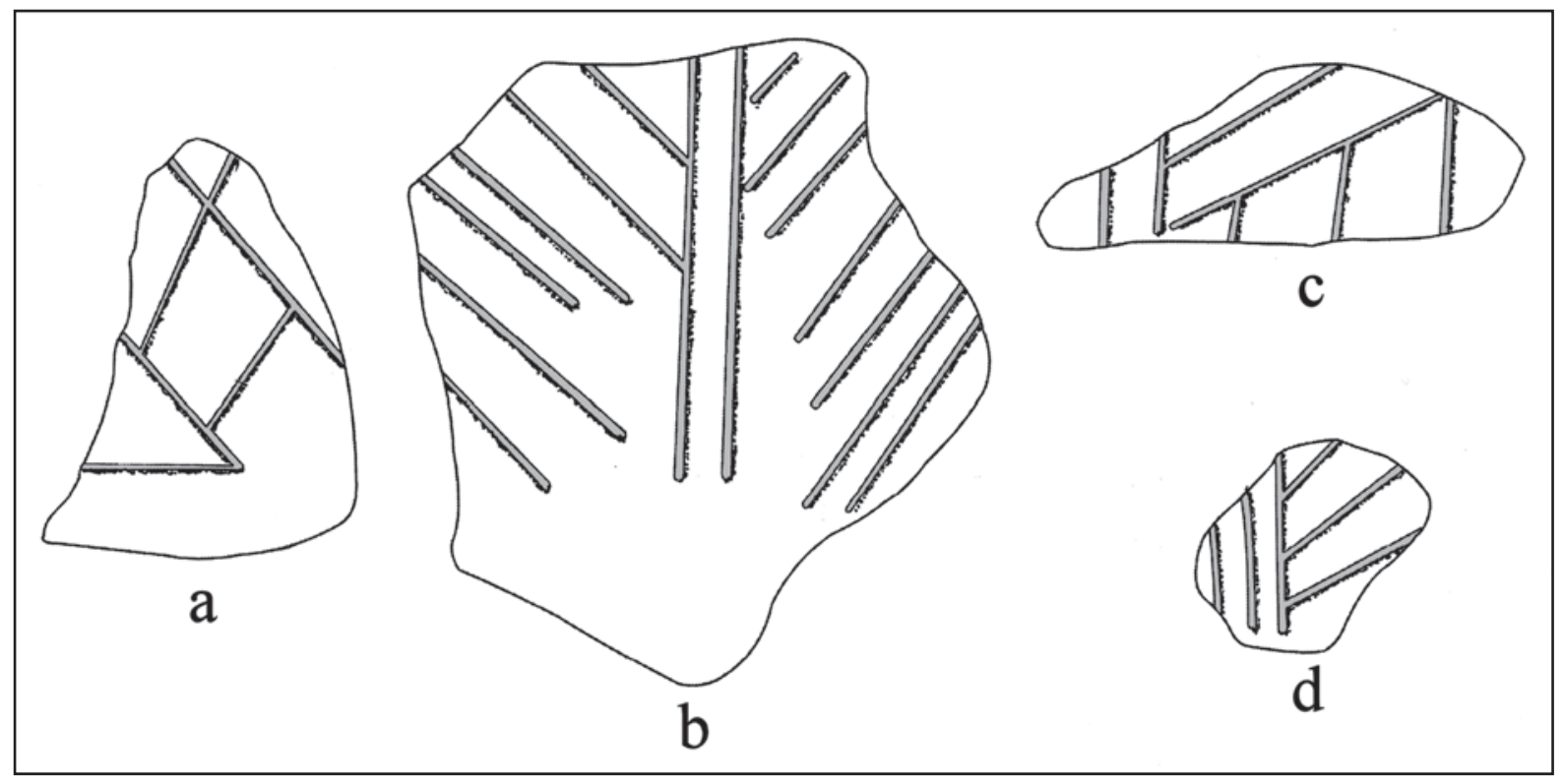

Figure 9. Selected decorative elements on incised shell-tempered utility ware sherds in the Head collection from the Roseborough Lake site.

The shell-tempered brushed, brushed-incised, and brushed-punctated sherds in the Head collection from the Roseborough Lake site are from shell-tempered varieties of Karnack Brushed-Incised (see Schambach and Miller 1984:123); grog-tempered examples of Karnack Brushed-Incised (see Suhm and Jelks 1962:85 and Plate 43) are also present in the Roseborough Lake collections (see below and Table $5)$. These vessels have horizontal brushed rims and vertical brushed marks and/or incised lines on the vessel body.

The shell-tempered fine ware sherds are dominated by sherds from vessels with engraved decorative elements, comprising about 90 percent of the assemblage (see Table 4). About 2.5 percent of the shelltempered fine ware sherds have engraved-incised decorative elements, another 7.5 percent have trailed decorative elements, and 0.8 percent have a slipped surface. Of the shell-tempered engraved fine wares identifiable to a defined type, sherds from Natchitoches Engraved $(n=19)$ vessels are most common (Figure 10a-i, m), followed by distinctive engraved sherds $(n=3)$ from short-rimmed Simms Engraved vessels (see Suhm and Jelks 1962:Plate 71b-c, f), and engraved-incised sherds from Hudson Engraved vessels (Figure 10j-k). One rim sherd with hatched engraved pendant triangles below the lip may also be from a Simms Engraved vessel (Figure 101) or a Womack Engraved vessel, as this type also has large pendant triangle motifs (Harris et al. 1965:Figure 6a; Story et al. 1967:Figure 50). 


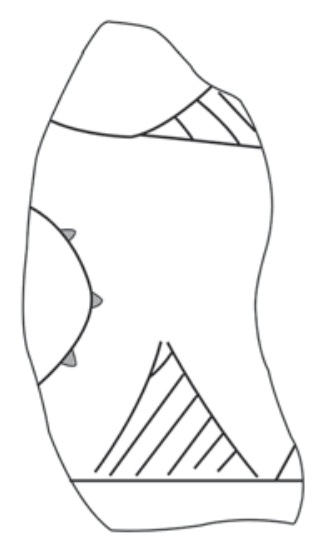

a

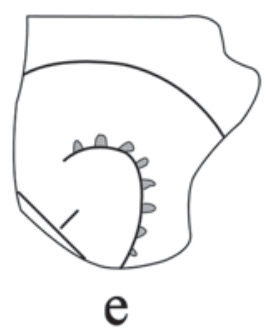

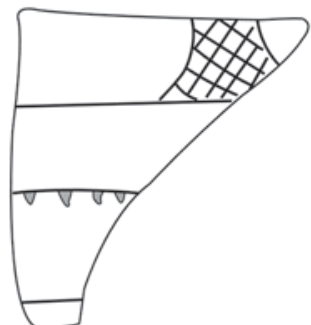

b

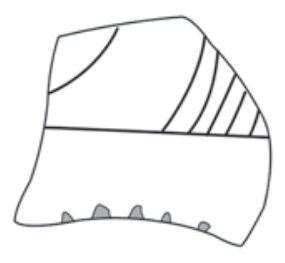

f

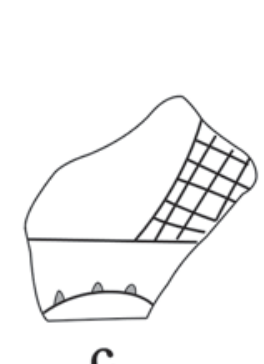

C

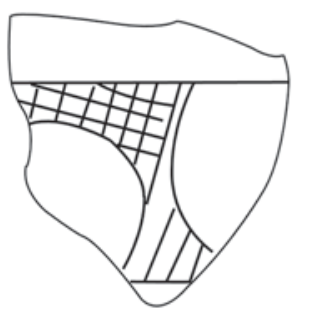

g

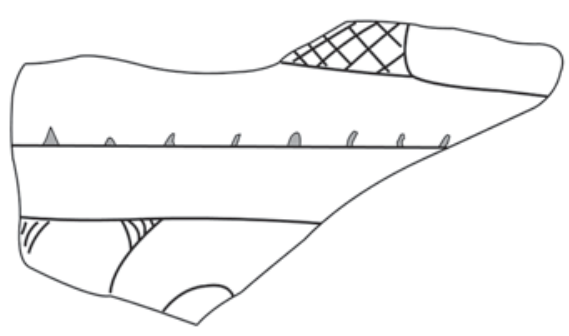

d
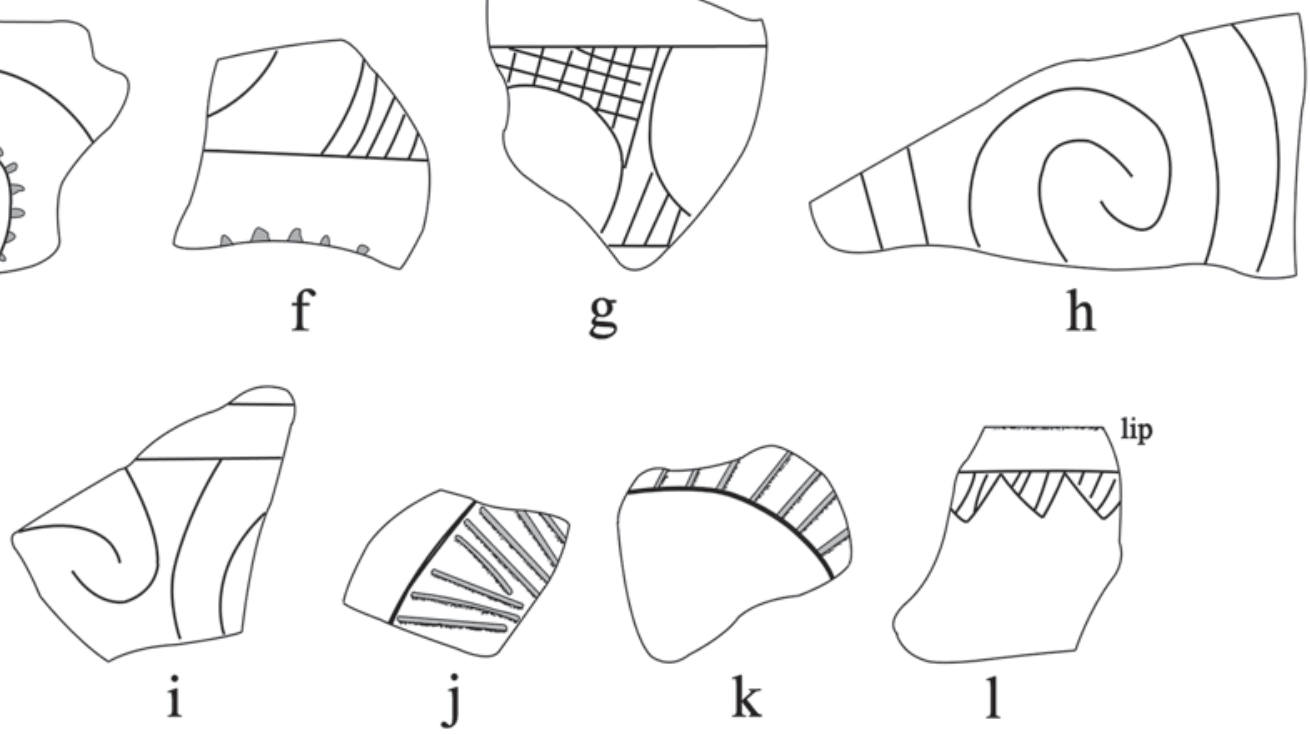

h

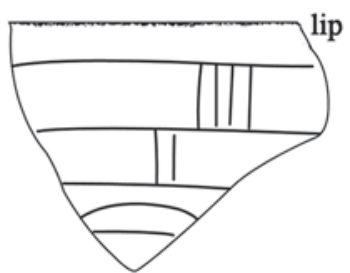

m

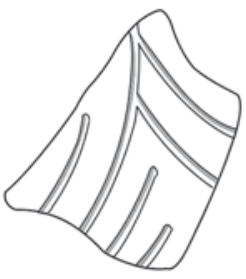

$\mathrm{n}$

Figure 10. Selected decorative elements on shell-tempered fine ware sherds in the Head collection from the Roseborough Lake site.

In the shell-tempered engraved assemblage as a whole (see Table 4), 25 percent of the sherds have excised tick marks on horizontal, diagonal, or curvilinear engraved decorative elements. Cross-hatched (25.9 percent of the engraved sherds) and hatched (13.8 percent) engraved zones of various shapes are common features present in the shell-tempered fine wares (see Figure 10a-d, f-g).

Shell-tempered Keno Trailed sherds are present in the Head collection from the Roseborough Lake site (see Figure 10n). Most of these sherds have sets of curvilinear trailed lines, and may be from var. McClendon or var. Glendora vessels (Schambach and Miller 1984:123). 
Grog-tempered utility ware sherds include sherds from both Ebarb Incised and Emory PunctatedIncised vessels (Table 5) (Figure 11a-b). However, sherds with incised decorative elements only comprise 56 percent of the utility wares compared to 81 percent in the shell-tempered utility wares from the site.

Table 5. Decorative elements in the grog-tempered vessel sherds in the Head collection from the Roseborough Lake site.

\begin{tabular}{llll}
\hline Decorative method and element & Rim & Body & $\mathrm{N}$ \\
\hline
\end{tabular}

Utility ware

Appliqued

diagonal opposed appliqued ridges

parallel appliqued ridges

straight appliqued ridge

$\begin{array}{lll}- & 1 & 1 \\ - & 1 & 1 \\ - & 3 & 3 \\ & & \\ - & 1 & 1\end{array}$

Appliqued-Punctated

straight appliqued fillet and tool punctated rows

1

Brushed

curvilinear brushed

horizontal brushed

parallel brushed

parallel brushed in zones

vertical brushed

(1)

1

3

Brushed-Incised

parallel brushed-incised lines

\section{Brushed-Punctated}

horizontal brushed and tool punctated row parallel brushed-tool punctated row through the brushing

\section{Incised}

circular incised el.

cross-hatched incised lines

curvilinear incised lines

diagonal incised lines (Ebarb Incised)

diagonal opposed incised lines (Ebarb

$-$

1

$-$

$-$

$-$

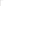

1

Incised)

horizontal-vertical incised lines (Ebarb

Incised)

opposed incised lines

parallel incised lines

parallel and cross-hatched incised lines

parallel-diagonal incised lines

straight incised line

straight and curvilinear incised lines (Emory

$-$

$-$

$\begin{array}{ll}1 & 1 \\ 1 & 1\end{array}$

Punctated-Incised)

straight and diagonal incised lines

straight-opposed incised lines

vertical and diagonal opposed incised lines

(Emory Punctated-Incised) 
Table 5. Decorative elements in the grog-tempered vessel sherds in the Head collection from the Roseborough Lake site, cont.

\begin{tabular}{llll}
\hline Decorative method and element & Rim & Body & $N$ \\
\hline
\end{tabular}

Incised-Lip Notched

diagonal incised lines-lip notched

Incised-Punctated

straight incised line-single tool punctate

Neck Banded

horizontal neck bands

Punctated

circular punctated rows

fingernail punctated rows

linear tool punctated rows

single tool punctate

tool punctated rows

$\begin{array}{lll}2 & 2 & 4 \\ 1 & 3 & 4 \\ 1 & 1 & 2 \\ - & 6 & 6 \\ 7 & 22 & 29 \\ & & \\ 1 & - & 1 \\ & & \\ - & 4 & 4 \\ 1 & - & 1 \\ - & 13 & 13 \\ - & 3 & 3 \\ 18 & 242 & 260\end{array}$

Punctated-Lip Notched

tool punctated row-lip notched

\section{Trailed}

curvilinear trailed lines (Foster Trailed-Incised)

horizontal trailed lines (Foster Trailed-Incised)

parallel trailed lines (Foster Trailed-Incised)

straight trailed line (Foster Trailed-Incised)

Sub-total, utility wares

\section{Fine ware}

\section{Engraved}

bracket-shaped cross-hatched engraved zone

circular engraved el.

circular engraved el. with tick marks

circular engraved el. with tick marks and triangleshaped cross-hatched el. (Natchitoches Engraved)

circular engraved el.-parallel engraved lines with cross-hatched pendant triangles

cross-hatched engraved zone

curvilinear engraved lines

curvilinear engraved lines and negative ovals

curvilinear engraved lines that end in hooked arms

curvilinear engraved lines with tick marks

curvilinear engraved line with tick marks and

narrow hatched zones

curvilinear engraved lines with tick marks and opposed

curvilinear engraved lines (Natchitoches Engraved)

circular engraved lines and narrow hatched zone

curvilinear engraved line and triangle hatched zone

curvilinear hatched zone

$\begin{array}{lll}- & 10 & 10 \\ - & 2 & 2 \\ - & 2 & 2 \\ - & 1 & 1 \\ - & 1 & 1 \\ - & 12 & \\ 1 & 15 & 12 \\ - & 1 & 16 \\ - & 1 & 1 \\ - & 5 & 5 \\ - & 1 & 1 \\ - & 1 & 1 \\ - & 1 & \\ - & 1 & 1 \\ - & 1 & 7\end{array}$


Table 5. Decorative elements in the grog-tempered vessel sherds in the Head collection from the Roseborough Lake site, cont.

\begin{tabular}{|c|c|c|c|}
\hline Decorative method and element & Rim & Body & $\mathrm{N}$ \\
\hline curvilinear hatched scroll fill zone & - & 1 & 1 \\
\hline curvilinear cross-hatched zones & - & 8 & 8 \\
\hline curvilinear cross-hatched zone and opposed engraved lines & - & 1 & 1 \\
\hline $\begin{array}{l}\text { curvilinear cross-hatched zones and negative } \\
\text { oval (Hodges Engraved) }\end{array}$ & - & 1 & 1 \\
\hline $\begin{array}{l}\text { diagonal engraved lines with tick marks and } \\
\text { hatched zones (Natchitoches Engraved) }\end{array}$ & 1 & - & 1 \\
\hline diagonal hatched engraved zone & - & 1 & 1 \\
\hline diagonal opposed engraved lines & - & 3 & 3 \\
\hline diagonal opposed engraved hatched zone & - & 1 & 1 \\
\hline hatched engraved triangle el. & 1 & 1 & 2 \\
\hline hatched engraved zones & - & 3 & 3 \\
\hline $2+$ horizontal engraved lines & 5 & 2 & 7 \\
\hline horizontal engraved lines (Simms Engraved) & 4 & 2 & 6 \\
\hline horizontal engraved lines and bracket el. & - & 2 & 2 \\
\hline $\begin{array}{l}\text { horizontal engraved lines, bracket el. and } \\
\text { raised ridge (Natchitoches Engraved) }\end{array}$ & - & 2 & 2 \\
\hline $\begin{array}{l}\text { horizontal engraved line and raised ridge } \\
\text { (Natchitoches Engraved) }\end{array}$ & - & 1 & 1 \\
\hline $\begin{array}{l}\text { 1+ horizontal engraved lines with tick marks } \\
\text { (Simms Engraved) }\end{array}$ & 3 & 6 & 9 \\
\hline $\begin{array}{l}\text { horizontal engraved panel filled with hatched } \\
\text { triangle el. (Simms Engraved) }\end{array}$ & 1 & - & 1 \\
\hline $\begin{array}{l}\text { horizontal engraved lines with tick marks and } \\
\text { hatched triangle el. }\end{array}$ & - & 2 & 2 \\
\hline $\begin{array}{l}\text { horizontal-diagonal-circular engraved lines } \\
\text { with tick marks and triangular hatched el. } \\
\text { (Natchitoches Engraved) }\end{array}$ & - & 1 & 1 \\
\hline horizontal and diagonal engraved lines (Simms Engraved) & 2 & 1 & 3 \\
\hline $\begin{array}{l}\text { horizontal engraved line with tick marks and } \\
\text { cross-hatched scroll fill el. (Natchitoches Engraved) }\end{array}$ & - & 1 & 1 \\
\hline horizontal-diagonal engraved lines and cross-hatched zone & 1 & - & 1 \\
\hline $\begin{array}{l}\text { horizontal and diagonal engraved lines and } \\
\text { raised ridge (Natchitoches Engraved) }\end{array}$ & - & 2 & 2 \\
\hline $\begin{array}{l}\text { horizontal and diagonal engraved lines with } \\
\text { tick marks (Natchitoches Engraved) }\end{array}$ & - & 1 & 1 \\
\hline horizontal and vertical engraved lines (Simms Engraved) & 3 & 1 & 4 \\
\hline horizontal and vertical engraved lines with tick marks & - & 1 & 1 \\
\hline $\begin{array}{l}\text { horizontal and vertical engraved lines with tick } \\
\text { marks and raised ridge (Natchitoches Engraved) }\end{array}$ & - & 1 & 1 \\
\hline horizontal, vertical, and diagonal engraved lines & 1 & - & 1 \\
\hline $\begin{array}{l}\text { horizontal, vertical, and diagonal engraved lines, } \\
\text { one line with tick marks }\end{array}$ & 2 & - & 2 \\
\hline opposed engraved lines & - & 5 & 5 \\
\hline opposed engraved lines and hatched triangle el. & - & 1 & 1 \\
\hline opposed engraved lines and cross-hatched zone & - & 1 & 1 \\
\hline opposed engraved lines with tick marks (Natchitoches Engraved) & - & 1 & 1 \\
\hline opposed curvilinear engraved lines & - & 1 & 1 \\
\hline parallel engraved lines & - & 23 & 23 \\
\hline
\end{tabular}


Table 5. Decorative elements in the grog-tempered vessel sherds in the Head collection from the Roseborough Lake site, cont.

\begin{tabular}{|c|c|c|c|}
\hline Decorative method and element & $\operatorname{Rim}$ & Body & $\mathrm{N}$ \\
\hline parallel engraved lines with tick marks & - & 6 & 6 \\
\hline $\begin{array}{l}\text { parallel engraved lines with tick marks and raised } \\
\text { ridge (Natchitoches Engraved) }\end{array}$ & - & 1 & 1 \\
\hline $\begin{array}{l}\text { parallel engraved lines with tick marks and } \\
\text { triangle-shaped cross-hatched zone }\end{array}$ & - & 1 & 1 \\
\hline parallel engraved lines and hatched triangle el. & - & 1 & 1 \\
\hline parallel-diagonal engraved lines with tick marks & - & 1 & 1 \\
\hline straight engraved line & - & 28 & 28 \\
\hline straight engraved line with tick marks & - & 13 & 13 \\
\hline straight-curvilinear engraved lines & - & 1 & 1 \\
\hline straight-diagonal engraved lines & - & 1 & 1 \\
\hline straight-diagonal engraved lines with tick marks & - & 1 & 1 \\
\hline triangular hatched zone & - & 3 & 3 \\
\hline triangular cross-hatched zone & - & 7 & 7 \\
\hline triangular and curvilinear cross-hatched zones & - & 1 & 1 \\
\hline vertical and diagonal opposed engraved lines & - & 1 & 1 \\
\hline \multicolumn{4}{|l|}{ Engraved-Incised } \\
\hline $\begin{array}{l}\text { engraved panel filled with incised lines (Hudson } \\
\text { Engraved) }\end{array}$ & - & 1 & 1 \\
\hline \multicolumn{4}{|l|}{ Engraved-Red-slipped } \\
\hline hatched engraved zone and ext. red-slipped & - & 1 & 1 \\
\hline \multicolumn{4}{|l|}{ Red-slipped } \\
\hline ext. red-slipped & - & 10 & 10 \\
\hline int. red-slipped & - & 1 & 1 \\
\hline int./ext. red-slipped & - & 8 & 8 \\
\hline \multicolumn{4}{|l|}{ Trailed } \\
\hline curvilinear trailed lines (Keno Trailed) & - & 10 & 10 \\
\hline $\begin{array}{l}\text { curvilinear trailed lines-ext. red-slipped (Keno } \\
\text { Trailed) }\end{array}$ & - & 1 & 1 \\
\hline 1+ horizontal trailed line (Keno Trailed) & - & 2 & 2 \\
\hline parallel trailed lines (Keno Trailed) & - & 5 & 5 \\
\hline sub-totals, fine wares & 25 & 244 & 269 \\
\hline Totals & 43 & 486 & 529 \\
\hline
\end{tabular}

Other important grog-tempered utility wares include punctated (primarily tool punctated) rim and body sherds (18 percent) from Emory Punctated-Incised vessels, an incised-punctated body sherd, Karnack Brushed-Incised rim and body sherds (14.6 percent), and Foster Trailed-Incised rim and body sherds (8.1 percent) (see Table 5). Also present in the grog-tempered utility wares in the Head collection from the Roseborough Lake site are sherds from Cass Appliqued vessels with appliqued ridges or fillets (2.3 percent) and a grog-tempered variety of Nash Neck Banded (0.8 percent). 


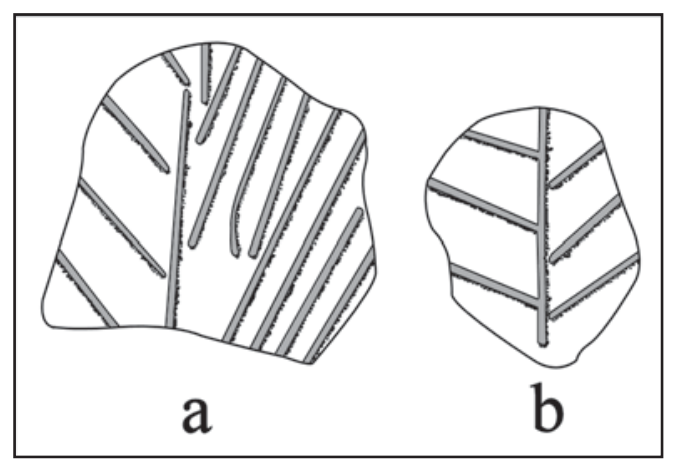

Figure 11. Selected decorative elements on incised grog-tempered utility ware sherds in the Head collection from the Roseborough Lake site.

Approximately 85 percent of the grog-tempered fine ware sherds in the Head collection have engraved decorative elements (see Table 5). More than 7 percent have red-slipped surfaces and no other decoration (compared to only 0.8 percent of the shell-tempered fine wares), one sherd ( 0.4 percent) has both engraved decorative elements and a red-slipped surface, and 6.7 percent are from Keno Trailed vessels. One sherd is from an engraved-incised Hudson Engraved vessel.

Of the sherds identified to a specific type, sherds from Simms Engraved vessels are most common in the grog-tempered fine wares from the Head collection. They comprise 10.0 percent of the engraved sherds ( $n=23$, see Table 5) (Figure 12j); only 2.8 percent of the shell-tempered engraved fine wares are from Simms Engraved vessels. Natchitoches Engraved vessel sherds $(n=14)$ account for 6.1 percent of the grog-tempered engraved fine wares (Figure 12a-f), compared to 16.7 percent of the shell-tempered engraved fine wares. Other sherds with distinctive hatched decorative elements (Figure 12g-i) may also be from Natchitoches Engraved vessels.

In terms of several specific attributes, the shell-tempered and grog-tempered engraved fine ware sherds are from vessels with comparable decorative elements and motifs. Between 23.0-25.0 percent of the engraved sherds from vessels made with different tempers have tick marks; 25.0 percent of the grog-bone-tempered engraved sherds also have tick marks (see below). Sherds with cross-hatched zones account for 20.0 (grog-tempered)-25.9 percent (shell-tempered) of the engraved sherds in the two different wares, while between 12.1 (grog-tempered) and 13.8 (shell-tempered) have hatched zones of various shapes. Thus, vessels with similar, if not exact, decorative motifs and elements at the Roseborough Lake site were made using two different temper aplastics: shell and grog.

About 77 percent of the decorated sherds from grog-bone-tempered vessels in the Head collection from the Roseborough Lake site are from utility ware vessels. These are primarily from vessels with incised decorative elements ( 52 percent of the utility ware sherds), likely from either Emory PunctatedIncised or Ebarb Incised vessels or brushed and brushed-incised sherds (30 percent of the utility ware sherds) from Karnack Brushed-Incised jars (Table 6). One rim sherd is lip notched but otherwise plain, one body sherd is from a grog-bone-tempered variety of Nash Neck Banded, and two sherds (8.7 percent of the utility ware sherds) have rows of tool punctations. The punctated sherds are from Emory Punctated-Incised vessels. 


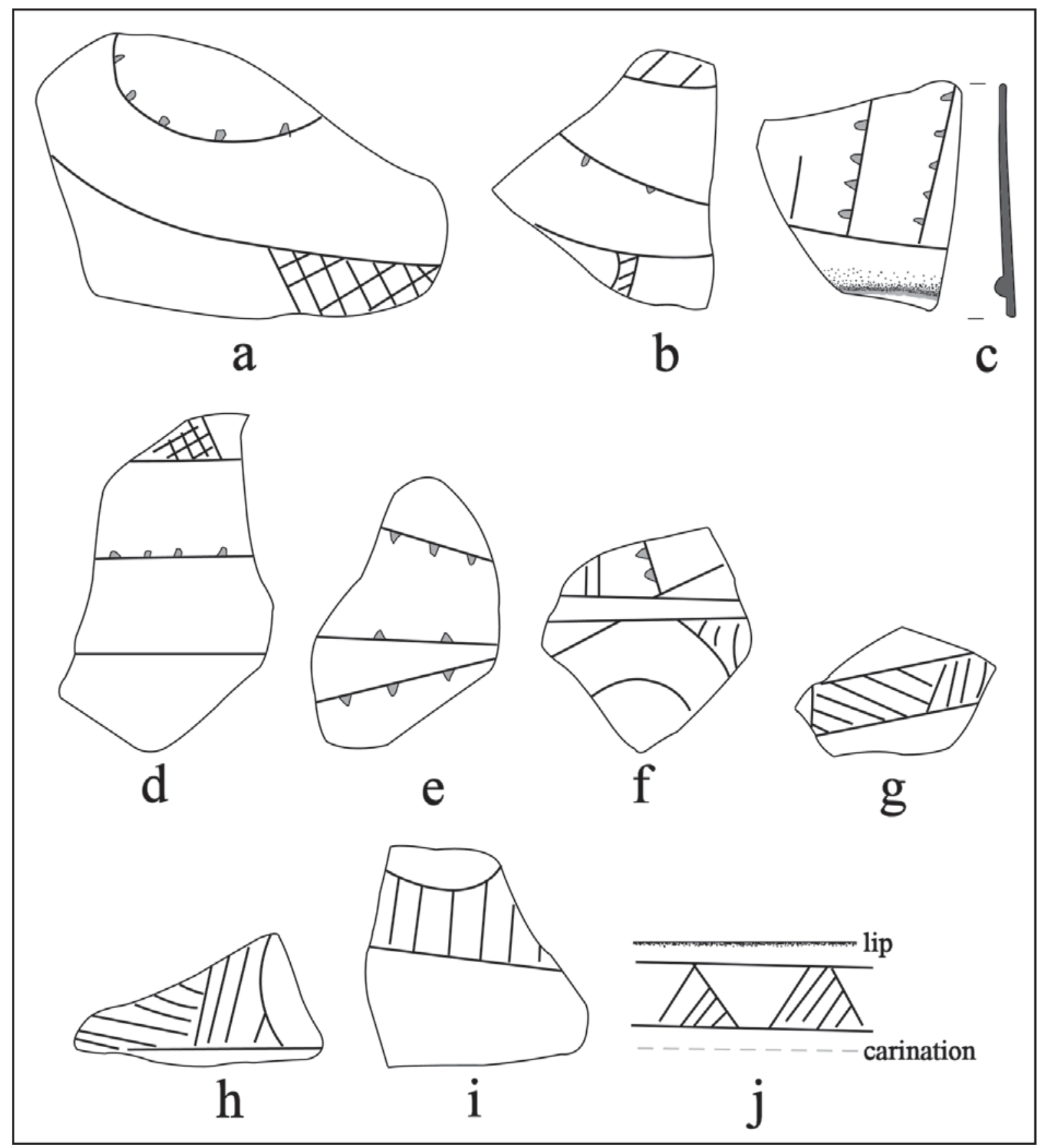

Figure 12. Selected decorative elements on grog-tempered fine ware sherds in the Head collection from the Roseborough Lake site. 
Table 6. Decorative elements in the grog-bone-tempered vessel sherds in the Head collection from the Roseborough Lake site.

\begin{tabular}{llll}
\hline Decorative method and element & Rim & Body & $\mathrm{N}$ \\
\hline
\end{tabular}

\section{Utility ware}

\section{Brushed}

parallel brushed

Brushed-Incised

parallel brushed-opposed incised lines

$\begin{array}{cll}- & 1 & 1\end{array}$

\section{Incised}

opposed incised lines

parallel incised lines

straight incised line

straight and diagonal incised lines

$\begin{array}{lll} & & \\ - & 1 & 1 \\ - & 6 & 6 \\ - & 4 & 4 \\ - & 1 & 1\end{array}$

\section{Lip Notched}

lip notched

Neck Banded

parallel neck banded rows

\section{Punctated}

tool punctated rows

\section{Fine ware}

\section{Engraved}

horizontal engraved lines with tick marks opposed engraved lines

straight engraved line

$\begin{array}{lll}1 & - & 1 \\ - & 1 & 1 \\ - & 2 & 2\end{array}$

\section{Engraved-Red-slipped}

hatched engraved zone and ext. red-slipped

Red-Slipped

int./ext. red-slipped

$\begin{array}{ll}- & 1\end{array}$

Trailed

curvilinear trailed lines (Keno Trailed)

The grog-bone-tempered fine ware sherds include one probable Simms Engraved vessel with horizontal engraved lines with excised tick marks, and two body sherds from red-slipped vessels; one body sherd has a hatched engraved zone, and may be from a Natchitoches Engraved vessel. One of the grog-bone-tempered fine ware sherds is from a Keno Trailed vessel (see Table 6). 
About 86 percent of the bone-tempered decorated sherds are from utility wares, particularly vessels with either incised or brushed decorative elements (Table 7). The remainder of the utility wares from vessels tempered with bone have either rows of fingernail or tool punctations. The brushed sherds are from the bodies of Karnack Brushed-Incised vessels, and the sherds with incised decorative elements are from Emory Punctated-Incised or Ebarb Incised vessels. The punctated sherds include both fingernail and tool punctated elements.

Table 7. Decorative elements in the bone-tempered vessel sherds in the Head collection from the Roseborough Lake site.

\begin{tabular}{llll}
\hline Decorative method and element & Rim & Body & N
\end{tabular}

\section{Utility ware}

\section{Brushed}

parallel brushed

$\begin{array}{ll}- & 4\end{array}$

\section{Incised}

parallel incised lines

straight incised line

straight-diagonal incised lines

$\begin{array}{lll}- & 4 & 4 \\ - & 1 & 1 \\ - & 1 & 1\end{array}$

Punctated

fingernail punctated row

linear tool punctated row

$\begin{array}{lll}- & 1 & 1 \\ - & 1 & 1\end{array}$

\section{Fine ware}

Engraved

parallel engraved lines and triangular hatched zone

$\begin{array}{cll}- & 1 & 1\end{array}$

\section{Red-Slipped}

ext. red-slipped

\begin{tabular}{ccc}
- & 1 & 1 \\
\hline 0 & 14 & 14
\end{tabular}

The bone-tempered fine ware sherds include both engraved and red-slipped decorative elements (see Table 7). Triangular hatched zones are a common decorative element in both the shell-tempered and grog-tempered fine wares at the Roseborough Lake site (see Tables 4-5), and the bone-tempered sherd may be from a Natchitoches Engraved vessel. The red-slipped sherd is untyped.

\section{Ceramic Spindle Whorls}

Two sherds have been worked into spindle whorls. Spindle whorls represent evidence of textile manufacture/weaving by the Caddo peoples living at the site. One, a circular grog-tempered body sherd from the general surface, has a $7.5 \mathrm{~mm}$ perforation. The other, a shell-tempered body sherd from the general surface, has a $9.9 \mathrm{~mm}$ perforation. 


\section{Ceramic Elbow Pipes}

There are portions of four ceramic elbow pipes in the Head collection from the Roseborough Lake site. The first pipe is a grog-tempered bowl sherd with engraved decorative elements, from no specific intra-site provenience. These include two horizontal engraved lines below the lip, and three diagonal hatched engraved triangles pendant from the lower horizontal engraved line. These hatched pendant triangles are separated from each other by single vertical engraved lines with excised tick marks (Figure 13b). The bowl has a flat lip, is $32.0 \mathrm{~mm}$ in height, and has a $29.6 \mathrm{~mm}$ bowl diameter. The outer diameter of the bowl hole is $15.0 \mathrm{~mm}$, and the diameter of the hole connecting the bowl to the stem is $6.3 \mathrm{~mm}$ at the bowl-stem juncture.

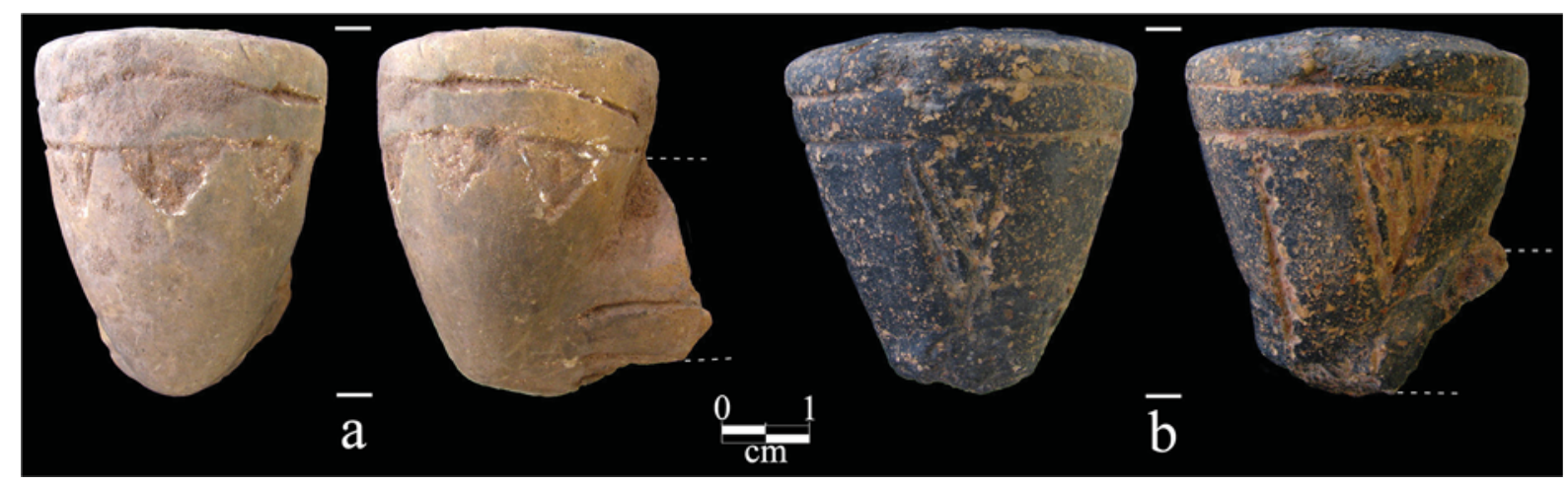

Figure 13. Engraved elbow pipe bowls from the Roseborough Lake site: a, lot 50; b, lot 14.

The second grog-tempered elbow pipe sherd is a bowl rim sherd with a flat lip, found in a general surface context (Lot 19). The bowl is decorated with three horizontal engraved lines, and the one closest to the lip has upward-pointing tick marks. The third elbow pipe sherd, from no specific provenience, is a grog-tempered rim with a flat lip. The bowl has at least one horizontal engraved line on it.

The fourth and last grog-tempered elbow pipe bowl in the collection has two horizontal engraved lines on the bowl as well as five hatched pendant triangles (see Figure 13a); a white kaolin clay pigment has been rubbed in the engraved elements. There are also at least three horizontal engraved lines on the remnant of the stem. The bowl height is $29.0 \mathrm{~mm}$, with an orifice diameter of $24.2 \mathrm{~mm}$; the bowl hole is $13.3 \mathrm{~mm}$ in diameter. The flat lip is $5.5 \mathrm{~mm}$ in thickness. The stem width at the bowl is $19.2 \mathrm{~mm}$, and the stem hole diameter is $12.0 \mathrm{~mm}$. A very similar engraved elbow pipe was recovered by Gilmore (1986:Figure I.5c) in Unit 6 excavations.

\section{Daub and Burned Clay}

Only a few pieces of daub $(n=3)$ and burned clay $(n=5)$ are represented in the surface collections from the site. They do indicate some clay plastering of structures there, as well as the use of clay hearths or earth ovens during the Nasoni Caddo occupation. 


\section{Chipped Stone Tools}

There are 87 chipped stone tools in the Head collection from the Roseborough Lake site. This includes 27 arrow points, four arrow point preforms, four dart points, 33 scraping tools, 15 flake tools, and four drills.

\section{Arrow points and arrow point preforms}

As previously mentioned, the Head collections from the Roseborough Lake site has 19 arrow points, eight arrow point tip and blade fragments, and four triangular-shaped arrow point preforms (Table 8). Seventeen (89 percent) of the arrow points are triangular-shaped forms (Figure 14a-i), variously called Fresno, Maud, or Talco points, and they are made from Ouachita Mountains cherts ( 71 percent) and novaculite ( 29 percent). Three of the four arrow point preforms are made from Ouachita Mountains chert, and one is made from a white novaculite.

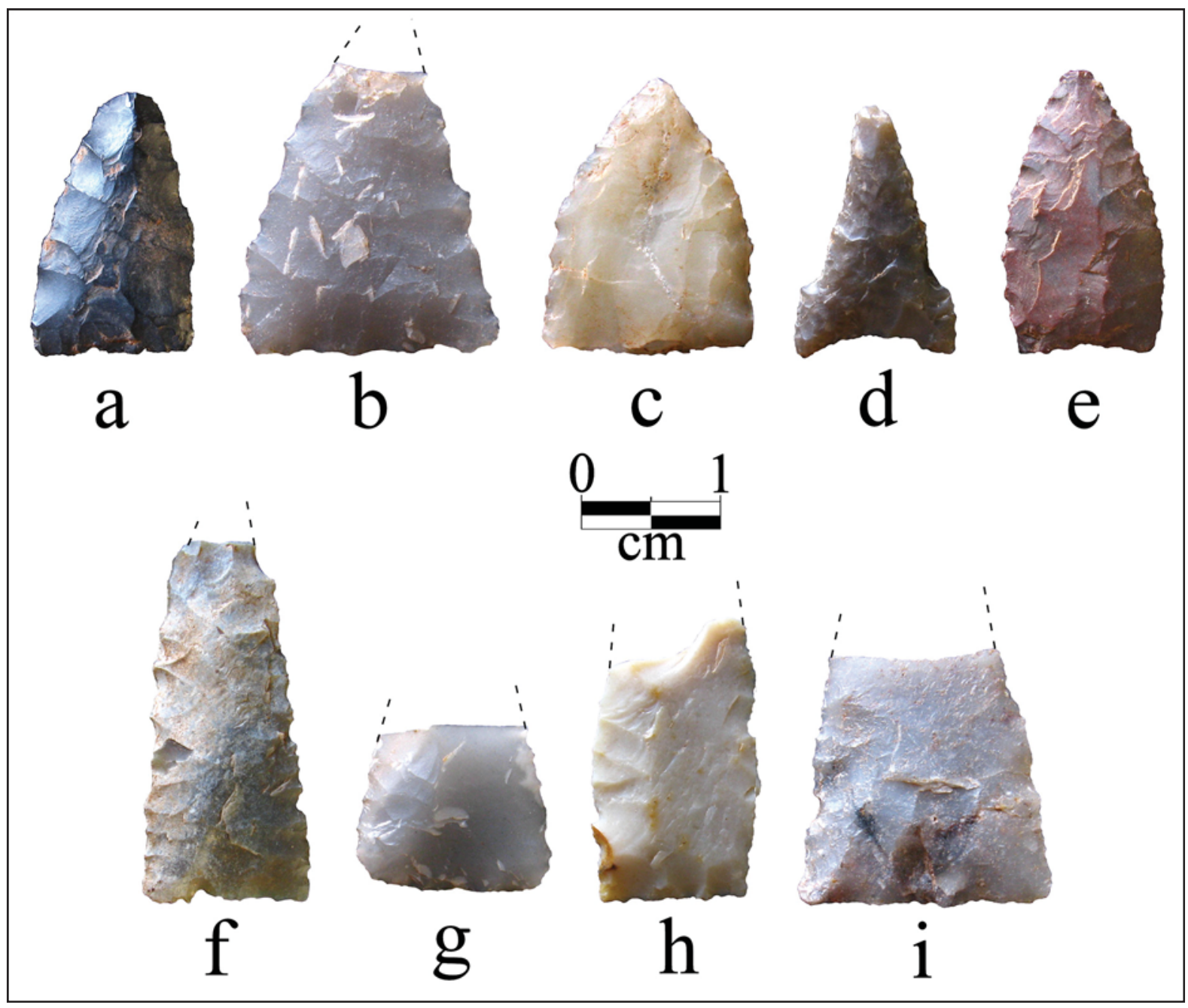

Figure 14. Triangular arrow points in the Head collection from the Roseborough Lake site. 
Table 8. Arrow points and arrow point preforms (not including tips and fragments) in the Head collection from the Roseborough Lake site.

\begin{tabular}{llll}
\hline Lithic raw material & $\begin{array}{l}\text { Triangular arrow } \\
\text { point form }\end{array}$ & $\begin{array}{l}\text { Other arrow } \\
\text { point forms }\end{array}$ & Preforms \\
\hline $\begin{array}{l}\text { brownish-gray chert } \\
\text { light gray chert }\end{array}$ & 1 & - & - \\
gray chert & 2 & - & - \\
dark gray chert & 4 & 1 & - \\
very dark gray chert & 1 & - & - \\
grayish-brown chert & 2 & - & - \\
grayish-white chert & - & 1 & 1 \\
black chert & 1 & - & - \\
gray novaculite & 1 & - & - \\
dark gray novaculite & 1 & - & - \\
white novaculite & 2 & - & 4 \\
white-gray novaculite & 1 & - & - \\
\hline Totals & 1 & - & \\
\hline
\end{tabular}

On Historic Caddo sites in East Texas, triangular arrow point forms predominate on sites from the Sabine River north to the Red River, while Perdiz, Cuney, and Turney arrow points occur almost exclusively on Historic Caddo sites in the Neches and Angelina river basins (Table 9). These mutually distinctive distributions suggest that there were two contemporaneous social networks of Caddo communities in East Texas in historic times: (1) a northern network of Kadohadacho, Nasoni, and Nadaco groups, and their descendants in the upper Sabine River basin, in the Red, Big Cypress, and Sabine river basins (areas in green on Figure 15), and (2) a southern Hasinai Caddo network of communities in the Neches and Angelina river basins (areas in red on Figure 15). Based on some shared ceramic vessel types, this latter network of Caddo communities were also interacting with Nadaco Caddo communities on the Sabine River as well as Caddo groups on the upper Sabine River basin (Figure 15).

Two of the arrow points have a different shape. They have barbs (either downward-pointed or at an angle to the blade), one point with a concave base (Figure 16a), or with an expanding stem and a concave base (Figure 16b). These arrow points are made from local Red River gravel cherts (see Table 8).

\section{Dart points}

There are four dart points in the Head collection from the Roseborough Lake site. These attest to the use of the natural levee landform well before the $18^{\text {th }}$ century Nasoni Caddo settlement, during Woodland period times (ca. 500 B.C.-A.D. 800). Miroir et al. (1973:123) reported that three of the four dart points they recovered at the site were Gary points; the other was an Edgewood point. These dart points include a red novaculite Gary point from the general surface; it is $7.3 \mathrm{~mm}$ thick and has a $12.9 \mathrm{~mm}$ stem width. Another Gary dart point, made from gray novaculite, came from the main collection area (see Figure 5), along with a gray chert dart point tip. A quartzite dart point tip and blade was from the main collection area at the site. 
Table 9. Distribution of arrow point forms on Historic Caddo sites in East Texas and Southwest Arkansas.

\begin{tabular}{|c|c|c|c|c|c|c|c|c|c|}
\hline Sites & Fresno & Maud & Harrell & Talco & Nodena & Turney & Perdiz & Cuney & SS \\
\hline \multicolumn{10}{|l|}{ Red River } \\
\hline 3LA97 & 8 & & & 4 & 8 & & & & \\
\hline 41BW2 & 4 & & & 1 & 1 & & & & 2 \\
\hline 41BW5 & 67 & 4 & 1 & 1 & & & & & \\
\hline 41LR1 & 863 & & 20 & & & & & & \\
\hline \multicolumn{10}{|c|}{ Sabine River } \\
\hline 41RA13 & 173 & 1 & 3 & 1 & & 1 & & & \\
\hline 41GG3 & ++ & & & & & & & & \\
\hline 41RK132 & 1 & & & & & & & & \\
\hline 41HS261 & 7 & & & & & & & & \\
\hline \multicolumn{10}{|c|}{ Neches and Angelina Rivers } \\
\hline 41AN2 & 2 & & & & & & 29 & & \\
\hline 41AN8 & & & & & & & & 1 & \\
\hline 41AN13 & & & & & 1 & 1 & 1 & & \\
\hline 41AN26 & 1 & & & & & 3 & & 3 & \\
\hline 41AN32 & & & & & & 11 & & & \\
\hline 41AN34 & & & & & & 1 & 1 & & \\
\hline 41CE6 & & & & & & & & 1 & \\
\hline 41CE25 & & & & & 5 & 29 & & & \\
\hline 41AN183 & & & & & & & 2 & & \\
\hline $41 \mathrm{HO} 64$ & & & & & & 1 & & & \\
\hline $41 \mathrm{HO} 211$ & & & & & 1 & 1 & 1 & & \\
\hline 41NA18 & & & & & & 2 & & & \\
\hline 41NA27 & & & 1 & & 1 & 118 & 3 & & \\
\hline 41NA60 & 4 & & & & & 4 & 1 & 3 & \\
\hline 41NA311 & & & & & & 1 & & & \\
\hline 41SM77 & & & & & & & & 1 & \\
\hline
\end{tabular}

$\mathrm{SS}==$ straight-stemmed, unidentified to type +++ present, but no. not specified

\section{Scrapers}

Chipped stone scraping tools are abundant in the Head collection from the Roseborough Lake site (Figure 17 and Table 10). Miroir et al. (1973:124) recovered 47 scrapers in their investigations: 72 percent were end scrapers and the remainder were side scrapers. In the Head collection, conversely, 72 percent of the scraping tools are end scrapers, another 12 percent are side scrapers, and the remaining 15 percent are end-side scrapers. All of the scrapers are made from high-quality Ouachita Mountains chert, particularly gray chert and dark gray chert. 


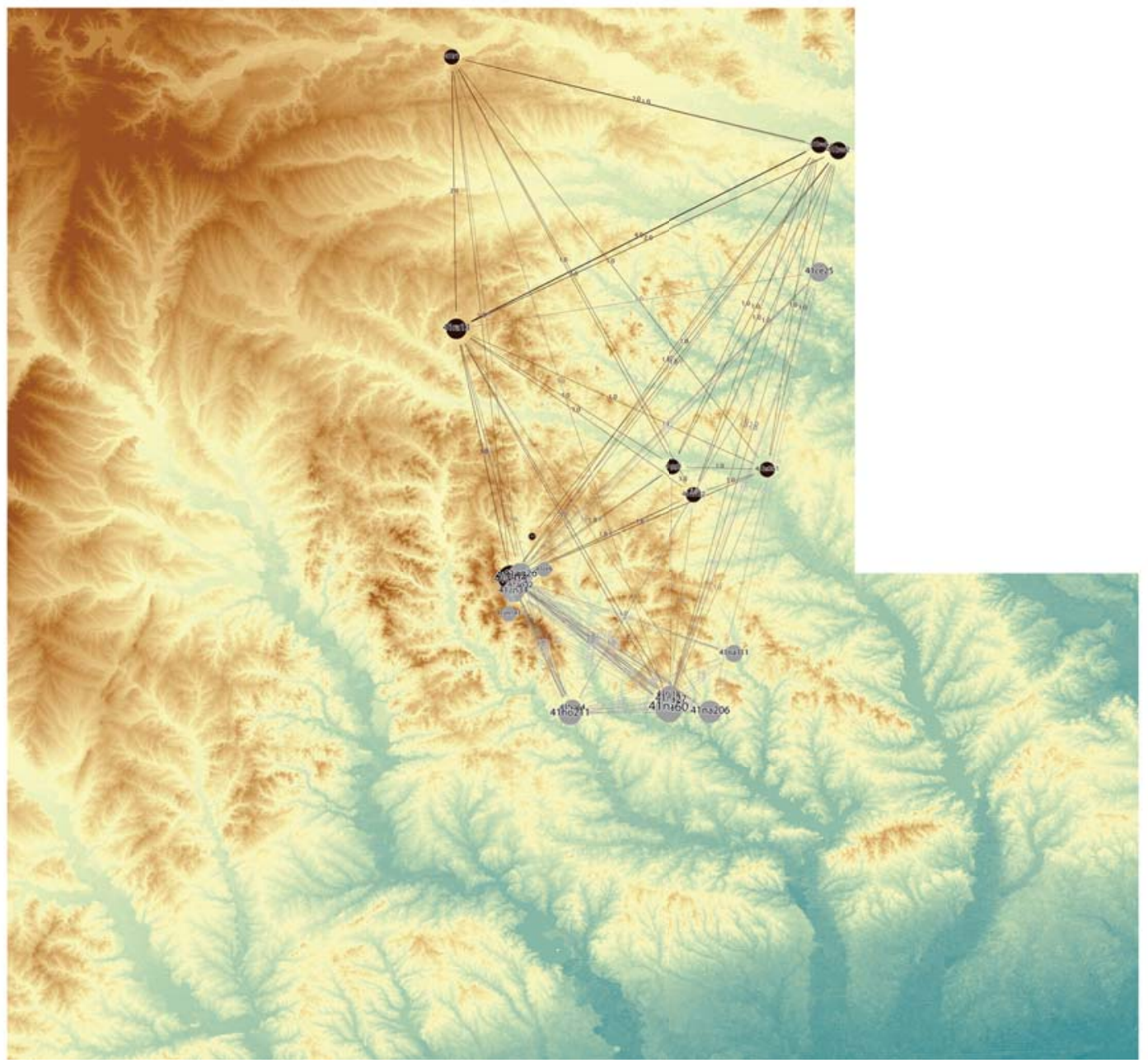

Figure 15. Social networks of northern and southern Historic Caddo groups in East Texas. Figure provided courtesy of Robert Z. Selden, Jr.

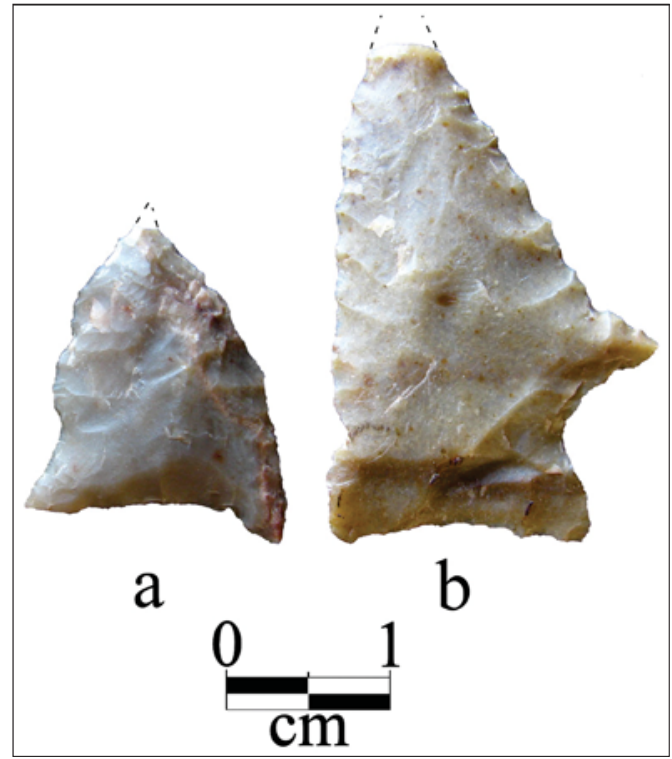

Figure 16. Other arrow point forms in the Head collection from the Roseborough Lake site. 


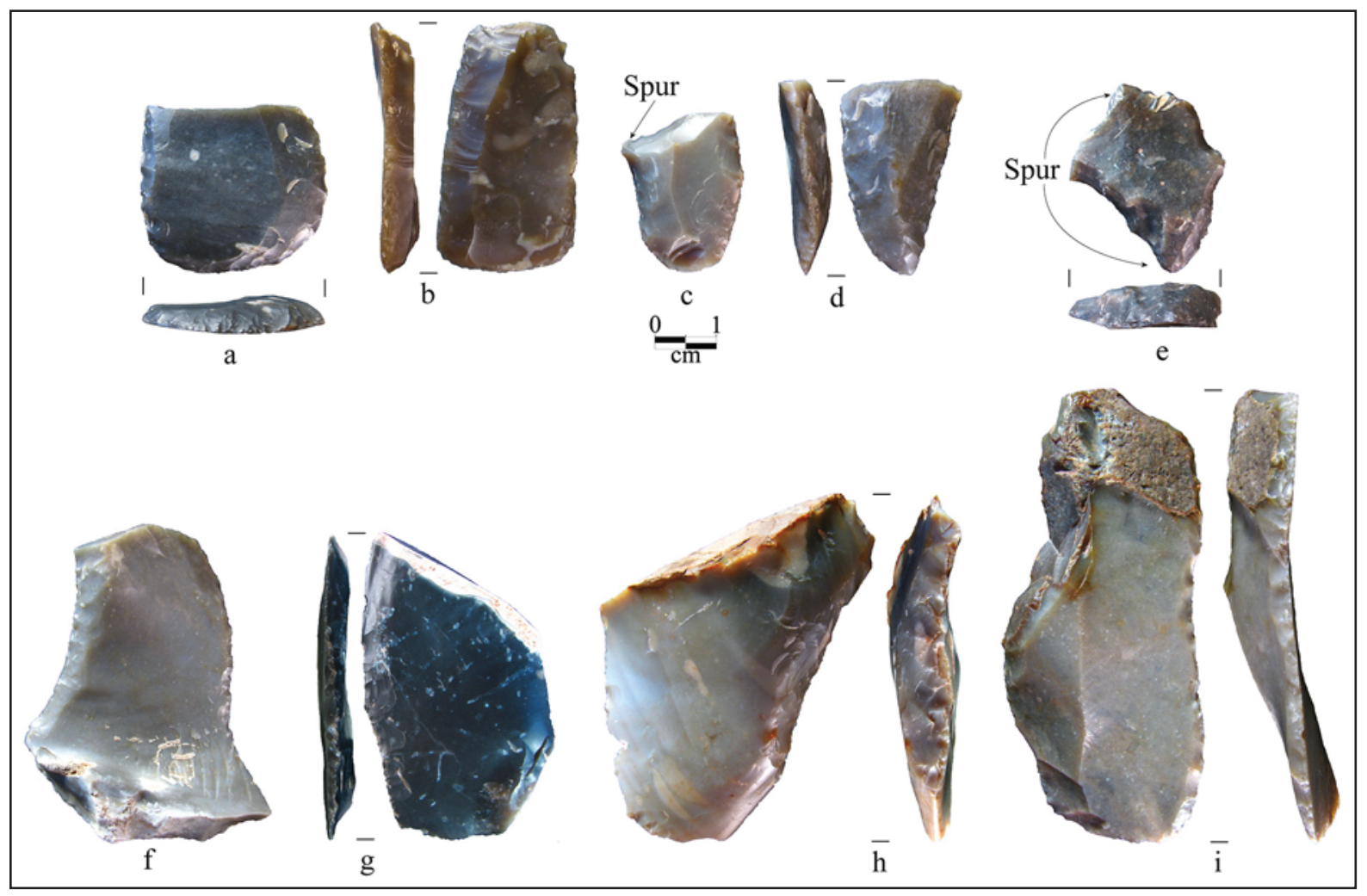

Figure 17. Scrapers in the Head collection from the Roseborough Lake site.

Table 10. Scrapers in the Head collection from the Roseborough Lake site.

\begin{tabular}{llcll}
\hline Raw material & \multicolumn{3}{c}{ Scraper category } & ES-SS \\
\hline SS & ES & - & 1 & 2 \\
brownish-gray chert & 1 & - & - & 1 \\
grayish-brown chert & 1 & - & - & 1 \\
light gray chert & 1 & 1 & 2 & 13 \\
gray chert & 10 & 1 & - & 3 \\
dark gray chert & 8 & 1 & 1 & 1 \\
very dark gray & 1 & - & - & 3 \\
grayish-black chert & 1 & 1 & 1 & 33 \\
black chert & 1 & 4 & 5 & \\
\hline Totals & 24 & & & \\
\hline
\end{tabular}

SS=side scraper; ES=end scraper; ES-SS=end scraper-side scraper

\section{Drills}

The four drills (Figure 18) in the Head collection have bifacially chipped drill stems They are manufactured on dark gray chert $(n=1)$ and a very dark gray chert $(n=3)$.

\section{Flake Tools}

The flake tools are expedient tools with unifacial or bifacial retouched or use-worn edges. All are made from Ouachita Mountains cherts, as was the case with the previously discussed scrapers, particularly gray and dark gray chert (Table 11). 


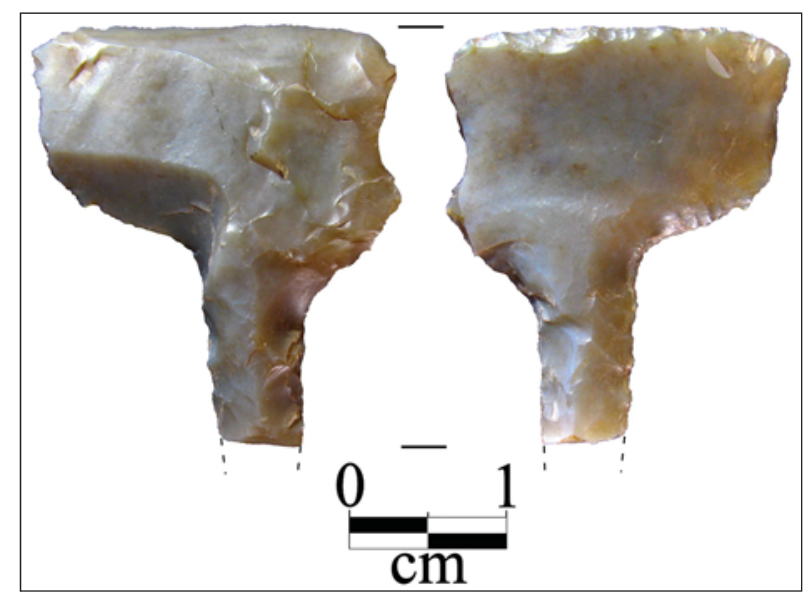

Figure 18. A drill in the Head collection from the Roseborough Lake site.

Table 11. Raw materials represented in the flake tools in the Head collection from the Roseborough Lake site.

\begin{tabular}{lll}
\hline Raw Material & No. & Percent \\
\hline grayish-brown chert & 1 & 6.7 \\
light gray chert & 1 & 6.7 \\
gray chert & 4 & 26.7 \\
dark gray chert & 6 & 40.0 \\
brownish-black chert & 1 & 6.7 \\
brownish-gray chert & 1 & 6.7 \\
black chert & 1 & 6.7 \\
\hline Totals & 15 & 100.0 \\
\hline
\end{tabular}

\section{Lithic Debris}

More than 211 pieces of lithic debris and one core are in the Head collection from the Roseborough Lake site. They have yet to be analyzed in any detail, but their presence at the 1719-1778 component at the site indicates that Caddo peoples were apparently reducing raw materials and knapping chipped stone tools here. The majority of the lithic debris appears to be from Ouachita Mountains cherts and novaculite raw materials available in local Red River gravel sources.

\section{Ground Stone Tools}

Two grinding stone fragments of ferruginous sandstone were collected from the surface at the Roseborough Lake site. They may also be associated with the Woodland period component.

\section{Fire-cracked Rock}

The surface collections include four pieces of fire-cracked rock. They are probably associated with hot rock cooking activities that took place during the Woodland period occupation of the Roseborough Lake site. 


\section{Marine Shell Artifacts}

One marine shell columella pin was found in the general vicinity of a possible burial just west of the main collection area (Figure 19) at the Roseborough Lake site. Another, $106 \mathrm{~mm}$ in length, was apparently associated with Burial 3 in the main collection area (Figure 20b), along with a third pin with a worked groove at its upper end (Figure 20a). Another marine shell columella pin, $82 \mathrm{~mm}$ in length, came from the vicinity of Burial 1 (Figure 20c). These columella pins have not been previously reported from the site by Miroir et al. (1973) and Gilmore (1986).

A marine shell bead was found in the general surface collection. The bead was $6.3 \mathrm{~mm}$ in length and 4.0 $\mathrm{mm}$ in width. Another shell bead was recovered in the vicinity of Head's Burial 3 in the main collection area.

\section{European Trade Goods}

\section{Glass Beads}

Glass beads are one of the more common European trade goods found on historic Caddo sites in East Texas and other regions. In the Head collection there is a total of 156 glass beads, all found on the disturbed surface of the Roseborough Lake site. They are categorized following Kidd and Kidd (1970) in Table 12.

Table 12. Glass beads from the Head collection from the Roseborough Lake site.

\begin{tabular}{|c|c|c|c|c|}
\hline Kidd and Kidd classification & Size & Color & Shape & $\mathrm{N}$ \\
\hline Ia5 & very small & white & tubular & 1 \\
\hline Ia5 & small & white & tubular & 5 \\
\hline Ia5 & medium & white & tubular & 1 \\
\hline Ia14 & medium & blue & tubular & 2 \\
\hline $\mathrm{Ib} 2$ & small & $\begin{array}{l}\text { red with } \\
2 \text { white } \\
\text { stripes }\end{array}$ & tubular & 1 \\
\hline IIa9 & very large & gray & round & 1 \\
\hline IIa13 & very small & white & round & 32 \\
\hline IIa13 & small & white & round & 66 \\
\hline IIa13 & medium & white & round & 7 \\
\hline IIa13 & large & white & round & 1 \\
\hline IIa13 & very large & white & round & 2 \\
\hline IIa31 & very small & blue & round & 1 \\
\hline IIa35 & small & light blue & round & 2 \\
\hline IIa40 & very small & blue & round & 2 \\
\hline IIa40 & small & blue & round & 2 \\
\hline IIa40 & large & blue & round & 3 \\
\hline IIa40 & very large & blue & round & 1 \\
\hline IIa43 & medium & blue & round & 1 \\
\hline IIa44 & medium & blue & round & 1 \\
\hline IIIa1 & small & $\begin{array}{l}\text { red with } \\
\text { black core }\end{array}$ & tubular & 1 \\
\hline IIIa1 & medium & $\begin{array}{l}\text { red with } \\
\text { black core }\end{array}$ & tubular & 5 \\
\hline IIIa1 & medium & $\begin{array}{l}\text { red with } \\
\text { black core }\end{array}$ & round & 1 \\
\hline
\end{tabular}




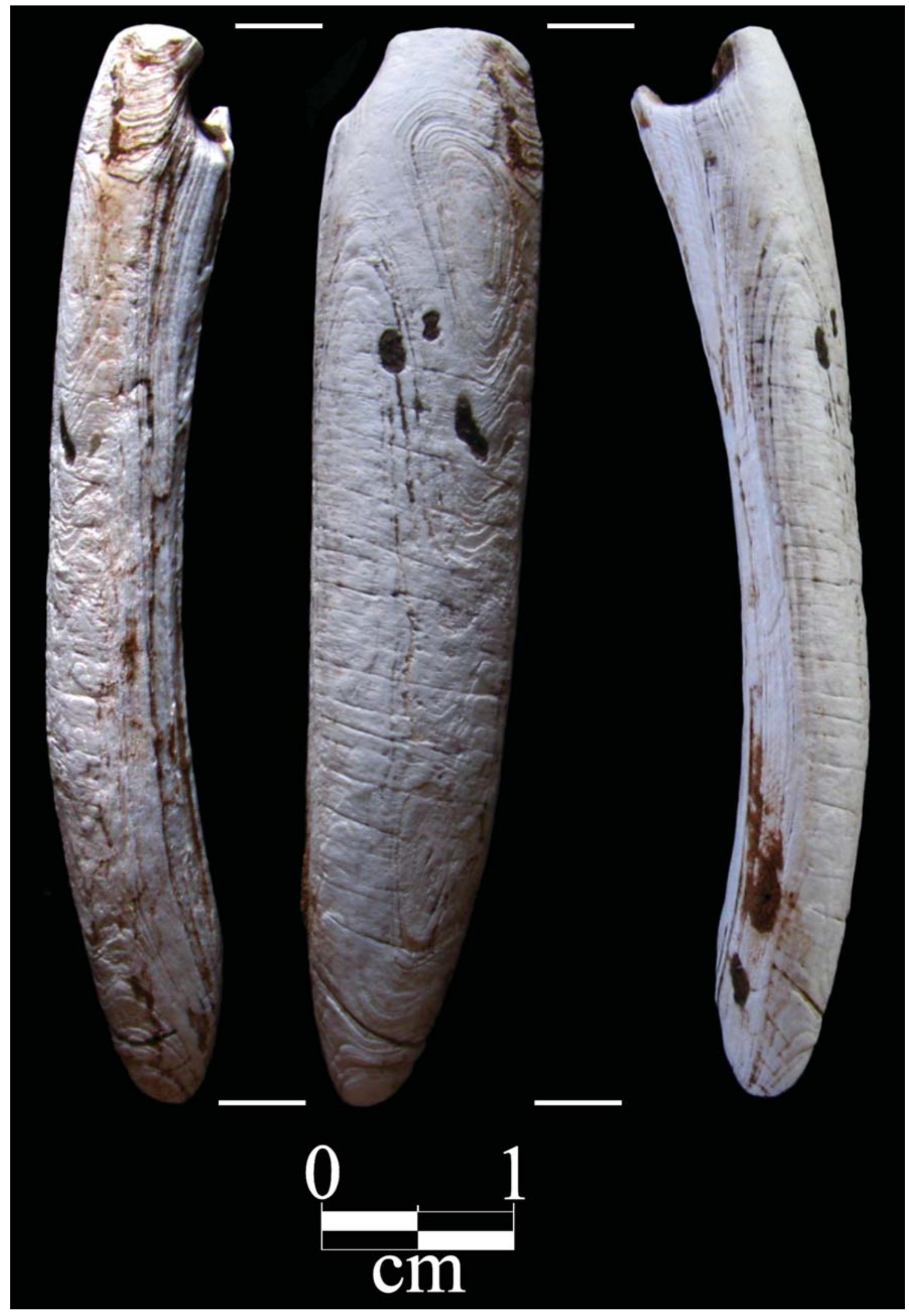

Figure 19. Marine shell columella pin from Lot 10A, general surface. 


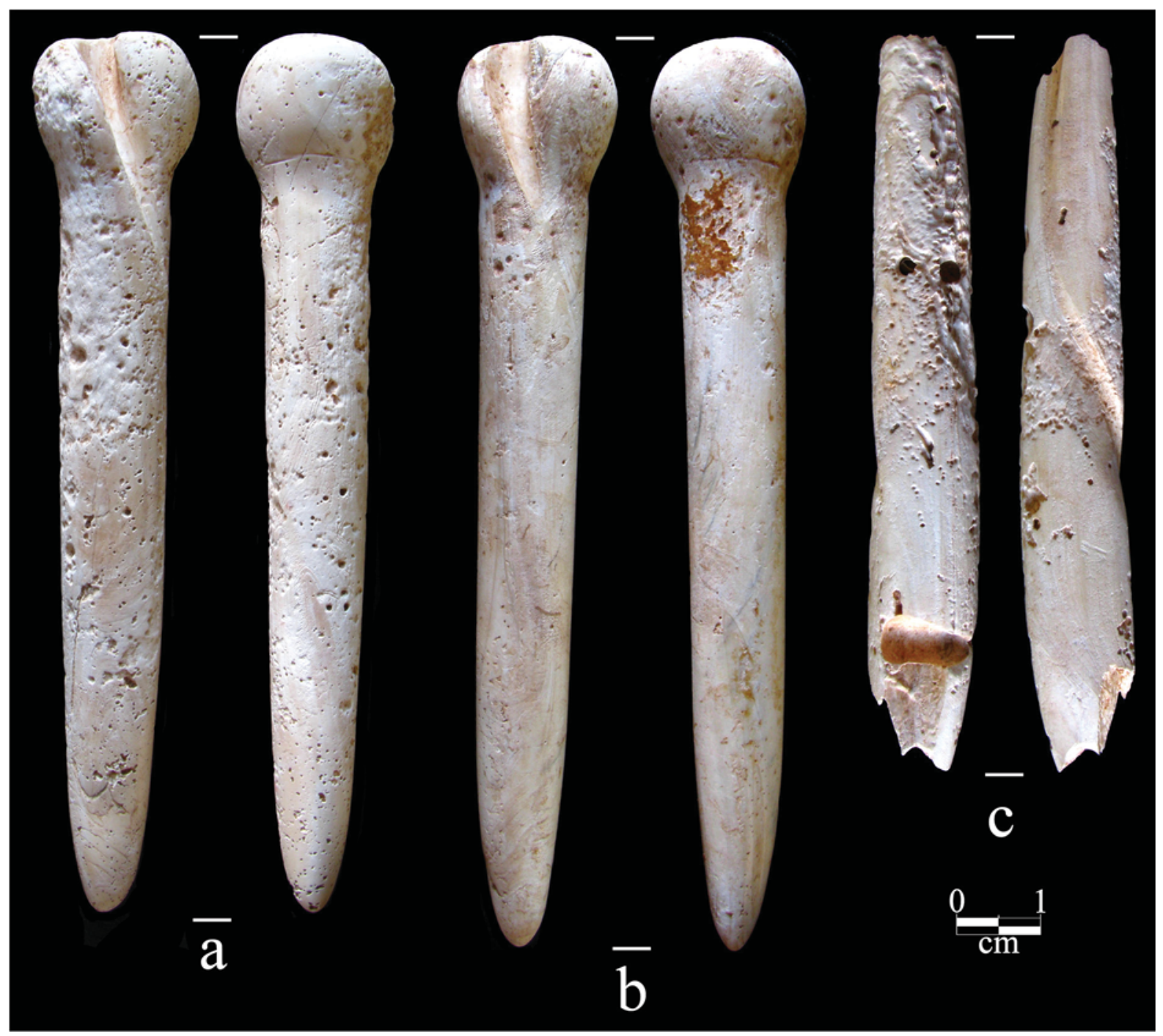

Figure 20. Marine shell columella pins: a, Lot 12A; b, vicinity of Burial 3 (Lot 12A); c, vicinity of Burial 1 (Lot 12B).

Table 12. Glass beads from the Head collection from the Roseborough Lake site, cont.

\begin{tabular}{lllll}
\hline Kidd and Kidd classification & Size & Color & Shape & N \\
\hline IIIb4 & small & $\begin{array}{l}\text { red with } \\
\text { black core; } \\
\text { sets of white } \\
\text { and black } \\
\text { stripes }\end{array}$ & tubular & 15 \\
& & light gold & round & \\
WIIe2 & blue & five-sided & 1 \\
WIIe8 & medium & very large & & \\
\hline
\end{tabular}

Most of the glass beads (79.5 percent) are round in shape, and range in size from very small $(<2 \mathrm{~mm}$ in diameter) to very large ( $>10 \mathrm{~mm}$ in diameter). Tubular beads comprise 19 percent of the bead sample, and there are two wire-wound beads (1.3 percent) (see Table 12). 
By color, 73.7 percent of the beads are white, and 10.3 percent are blue in color (Figures 21a-b). Red beads with black cores (Cornaline d'Aleppo beads) comprise only 4.5 percent of the assemblage, and red beads with white or white and black stripes account for another 10.3 percent of the Roseborough Lake beads. The remaining bead colors are gray ( $n=1,0.6$ percent) and light gold ( $n=1,0.6$ percent).

Other bead assemblages from Roseborough Lake are predominantly white (48 percent) and blue (45 percent) in color (Avery 2008:Table 1), with small numbers of red (4.8 percent), black (1.4 percent), green $(0.4$ percent $)$, amber ( 0.3 percent), and clear ( 0.2 percent). Caddo sites in East Texas with a predominance of white beads are most common among Caddo populations that lived along the Red and Sabine rivers, except for the Nacogdoche Caddo Spradley site (41NA206) in the Angelina River basin (Avery 2008:Figure 4).

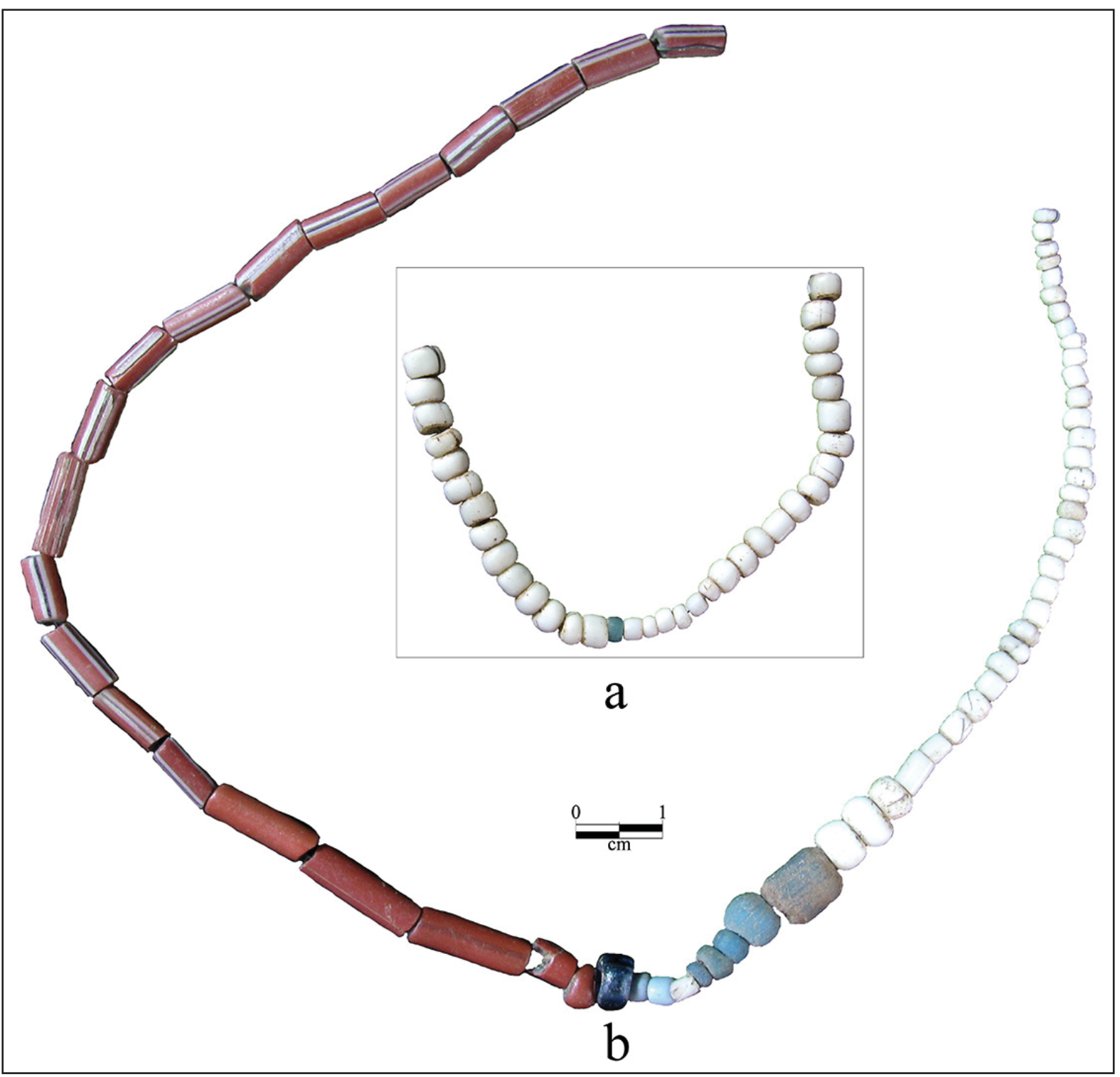

Figure 21. A sample of glass beads in the Head collection from the Roseborough Lake site: a, Lot 12B; b, Lot 37. 


\section{Gun Parts}

One French brass side plate fragment from a Type D gun (see Hamilton 1976:Figure 14r-t), with the upper screw hole visible, is in the Head collection from the Roseborough Lake site. The side plate has an engraved design (Figure 22f), including horizontal engraved lines at the top and bottom of the side plate, and a central ribbon-like engraved design similar to a ca. 1730s-1760s side plate from the Gilbert site (41RA13) (Blaine and Harris 1967:Figure 38g). One possible gun part in the collection is a curved piece of brass, $2.9 \mathrm{~mm}$ in thickness, that may be part of a trigger guard, possibly along the rear tang (cf. Blaine and Harris 1967:Figure 40e).

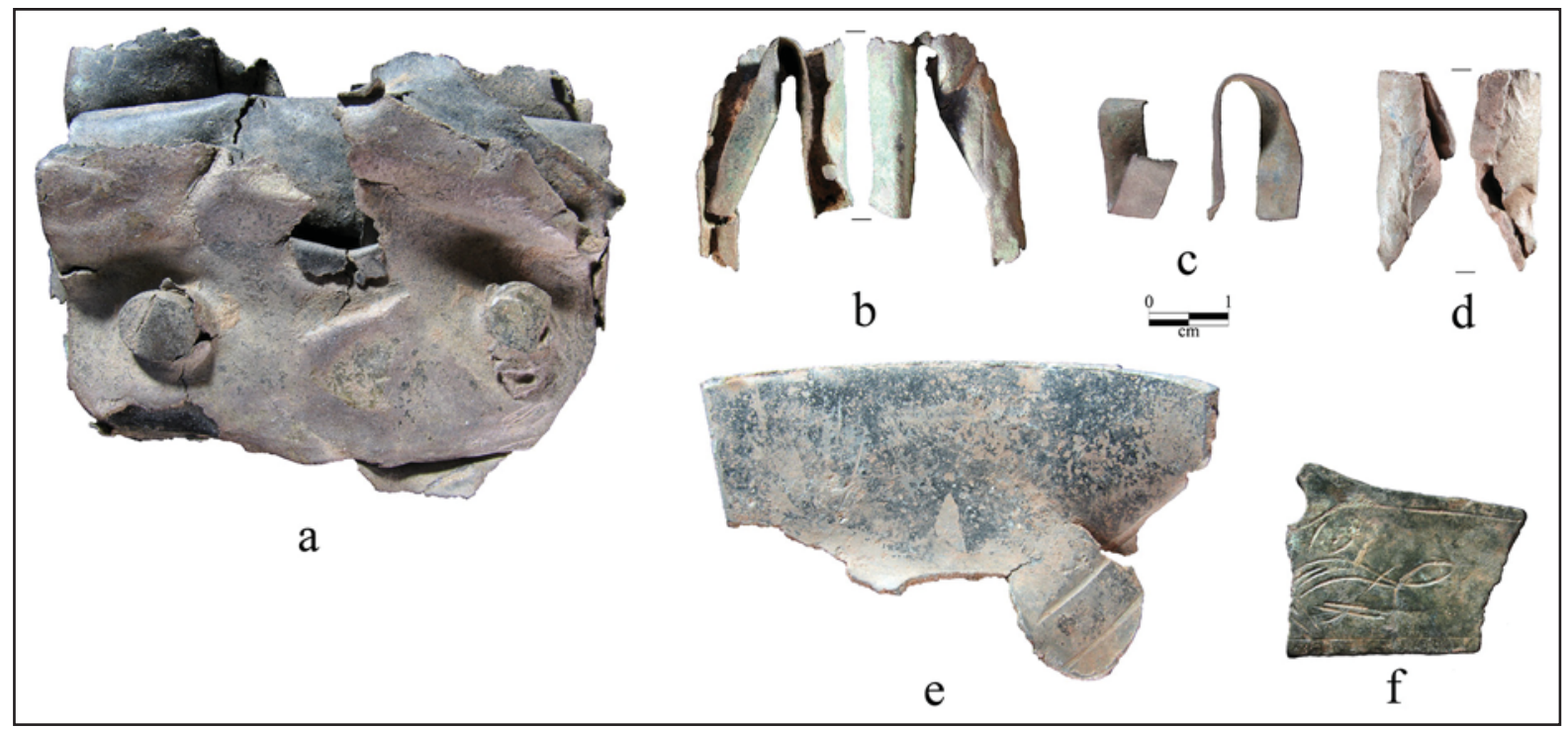

Figure 22. Other metal artifacts in the Head collection from the Roseborough Lake site.

\section{Gunflints}

There are 14 gunflints in the Head collection from the Roseborough Lake site. Those with a specific provenience were found primarily in the main Head collection area (see Figure 5), namely Lots 9 and 20.

The gunflints include 12 spall or wedge-shaped flints (Figure $23 \mathrm{~b}$-j), one blade gunflint (Figure 23a), and one possible native-made gunflint (Table 13). Three of the gunflints are made from a honey or yellowish-blonde French flint (Figure 23a-b, g) (Hamilton [1979:210] refers to this as beeswax flint), the possible native-made gunflint is on a dark brown chert that may have been collected from Red River gravels (it is also the largest of the gunflints in the collection), while the remainder are gray $(\mathrm{n}=6)$, light gray to gray $(n=1)$, whitish-gray $(n=2)$, whitish-black $(n=1)$ cherts.

Table 13. Gunflints in the Head collection from the Roseborough Lake site.

\begin{tabular}{lllll}
\hline Lot No. & Type & Raw Material & $\begin{array}{c}\text { Length* } \\
(\mathrm{mm})\end{array}$ & $\begin{array}{l}\text { Width* } \\
(\mathrm{mm})\end{array}$ \\
\hline 9 & Spall & gray chert & 23.9 & 17.9 \\
9 & Spall & whitish-gray & 23.6 & 19.1 \\
9 & Blade & honey-blonde chert & 20.4 & 17.2 \\
9 & Spall & honey-blonde chert & 23.0 & 14.9 \\
9 & Spall & whitish-gray chert & 22.0 & 18.8 \\
9 & Spall & light gray-gray chert & 20.9 & 20.3
\end{tabular}




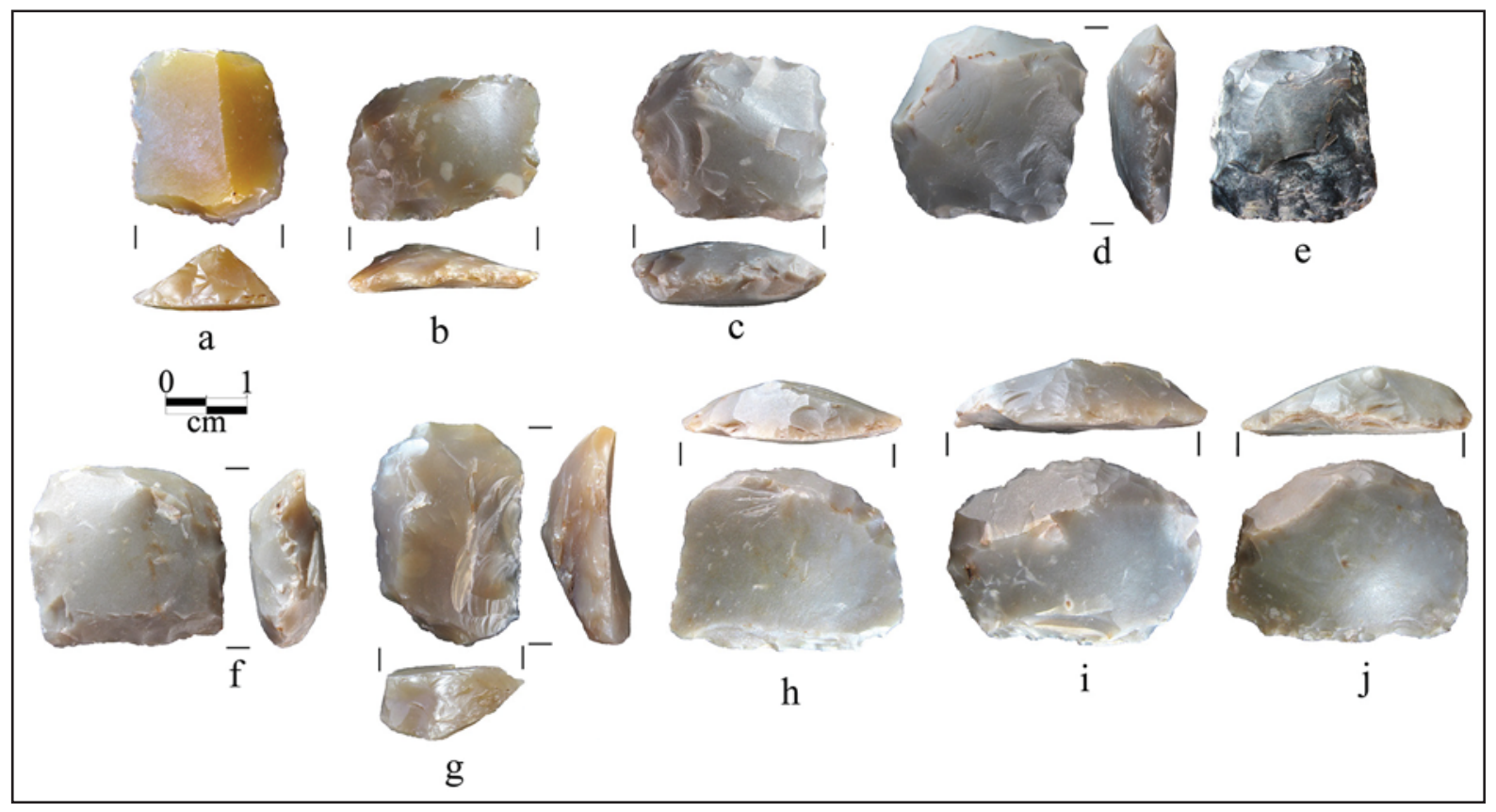

Figure 23. Gunflints in the Head collection from the Roseborough Lake site.

Table 13. Gunflints in the Head collection from the Roseborough Lake site, cont.

\begin{tabular}{lllll}
\hline Lot No. & Type & Raw Material & $\begin{array}{l}\text { Length* } \\
(\mathrm{mm})\end{array}$ & $\begin{array}{l}\text { Width* } \\
(\mathrm{mm})\end{array}$ \\
\hline 9 & Spall & honey-blonde chert & 25.0 & 16.9 \\
9 & Spall & gray chert & 26.1 & 21.0 \\
$10 \mathrm{~A}$ & Spall & gray chert & 27.2 & 21.0 \\
20 & Native & dark brown chert & 32.9 & 20.9 \\
20 & Spall & gray chert & 29.3 & 20.9 \\
27 & Spall & gray chert & 21.2 & 21.0 \\
30 & Spall & whitish-black chert & 19.3 & 17.9 \\
30 & Spall & gray chert & 21.2 & 19.2 \\
\hline
\end{tabular}

*length is from one side to the other of the gunflint, and width is heel to edge (Hamilton 1979:210; see also Kenmotsu 1990:Figure 7)

The blade gunflint in the Head collection is $20.4 \mathrm{~mm}$ in length and $17.2 \mathrm{~mm}$ in width, while the spall gunflints range from 19.3-29.3 mm in length and 14.9-21.0 mm in width (see Table 13). These shape measurements suggest that all the gunflints have been used and reworked before being discarded (cf. Hamilton 1979:210).

Miroir et al. (1973:149-152) identified 70 spall or wedge-shaped gunflints and 11 blade gunflints of European origin, and three possible Native American-made gunflints, in earlier investigations at the Roseborough Lake site. The spall gunflints are cherts ranging in color from light to dark shades of tan, gray to grayish-black, and white, gray, and light pink. The blade gunflints are made of yellowish-blonde French flint. The Native-made gunflints are quartzite and jasper found in Red River gravels. 


\section{Lead Balls, Shot, and Sprue}

A total of 19 lead balls and 20 lead shot are in the collection. Twelve of the lead balls are flattened from impact (Figure 24b, g); these range from 10.7-16.9 grams in weight. The undeformed lead balls (Figure 24a, c-f) range from 12.5-14.4 mm in diameter and weigh between 14.1-17.2 mm (Table 14). These balls are consistent in size with balls used on French trade guns with bores ranging from .54 inches to .59 inches, and .51-.56 caliber; these were balls between 28-32 to the pound (Miroir et al. 1973:155158; Hamilton 1976:33). The balls are too small to be for use in French musketoon, dragoon, or infantry bore weapons (Hamilton 1979:Table 16).

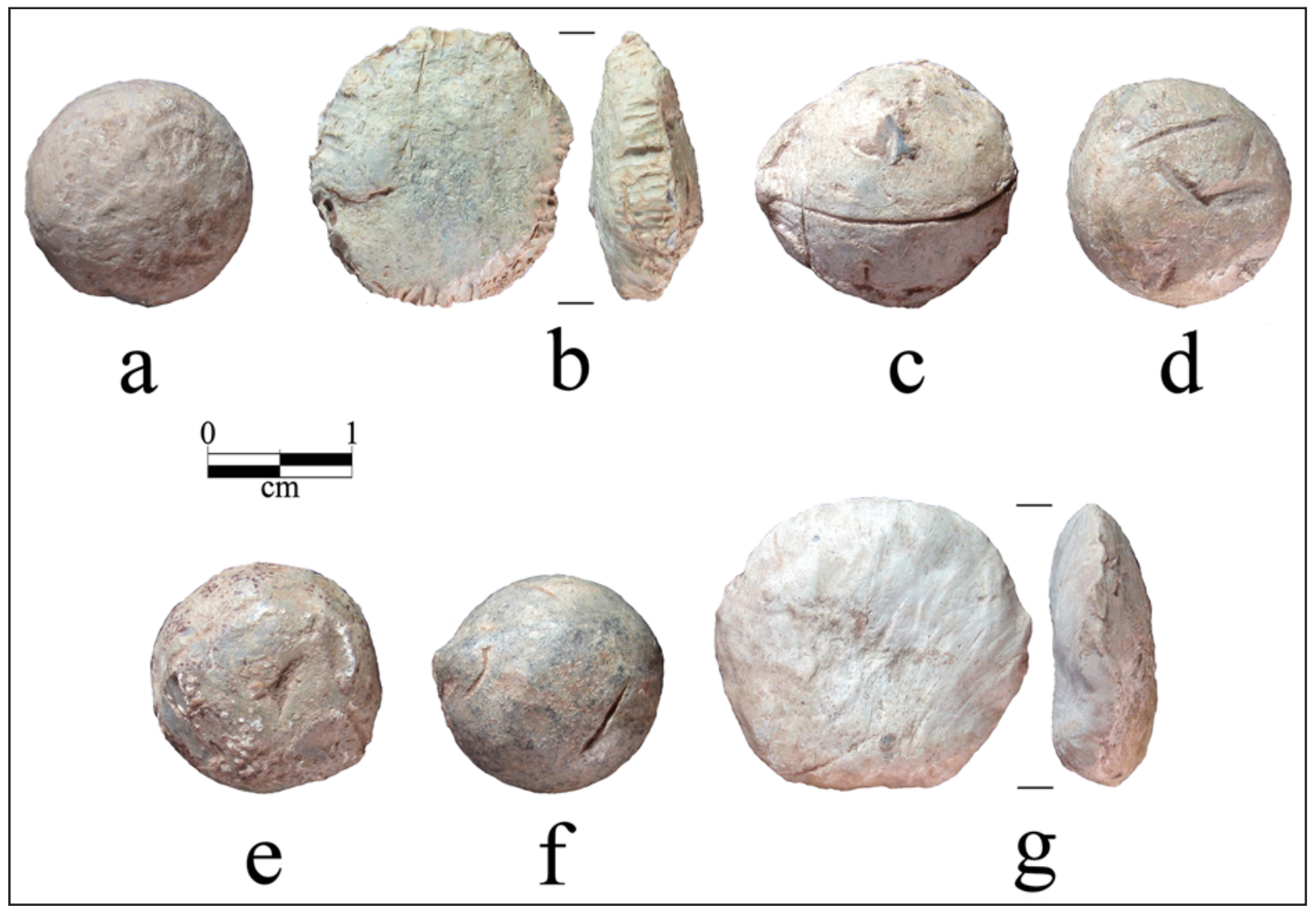

Figure 24. Lead balls from the Head collection from the Roseborough Lake site.

Table 14. Lead ball diameters and weights in the Head collection from the Roseborough Lake site.

\begin{tabular}{lll}
\hline Lot No. & Diameter $(\mathrm{mm})$ & Weight $(\mathrm{grams})$ \\
\hline 31 & 12.5 & 16.5 \\
41 & 12.7 & 14.1 \\
41 & 13.1 & 15.1 \\
41 & 13.9 & 15.5 \\
41 & 13.9 & 17.2 \\
41 & 14.4 & 16.2 \\
50 & 13.9 & 16.1 \\
\hline
\end{tabular}


The lead shot occurs in several different sizes. The larger shot $(\mathrm{n}=8)$ range from 7.4-10.7 $\mathrm{mm}$ in diameter and weigh between 2.5-7.6 grams (Figure 25a, c-d). The size of the shot is comparable to what Hamilton (1976:35) calls buck and swan shot. The remainder of the shot falls between 5.5-6.4 mm in diameter $(\mathrm{n}=2)$ (Figure 25b) or between 1.8-4.1 mm in diameter $(\mathrm{n}=10)$. These pieces of shot have dimpled surfaces, and range in weight from 0.1-2.6 grams. According to Hamilton (1976:208) shot was used as often as lead balls in the "French 32 and 28 calibre smooth bores."

There are five pieces of lead sprue in the Head collection (Figure 26a-b), weighing a total of 60.8 grams, and ranging from 3.8 to 17.4 grams. These are evidence for the on-site manufacture of lead balls.

\section{Other Metal Artifacts}

One of the other metal artifacts in the collection is a folded sheet of lead, of unknown use, that is $41.0 \mathrm{~mm}$ in length and $10.2 \mathrm{~mm}$ in diameter. The lead piece weighs 21.1 grams. Two other lead fragments are rolled and one is cut (see Figure 22d). There are also cut and/or folded cupreous sheet fragments $(\mathrm{n}=8)$ between $0.8-2.3 \mathrm{~mm}$ in thickness (see Figure 22c).

There is also a cast brass kettle bail ear with two copper rivets (see Figure 22a). The three pieces (with a total thickness of $6.1 \mathrm{~mm}$ ) of folded sheet brass comprising the kettle bail ear are $6.1 \mathrm{~mm}$ in thickness, and form a $67 \times 49 \mathrm{~mm}$ rectangle. A sheet brass kettle rim $(2.3 \mathrm{~mm}$ thick $)$ is also in the collection (see Figure 22e). Two sheet brass tinkler fragments, one at least $15 \mathrm{~mm}$ in length, are in the collection (see Figure 22b).

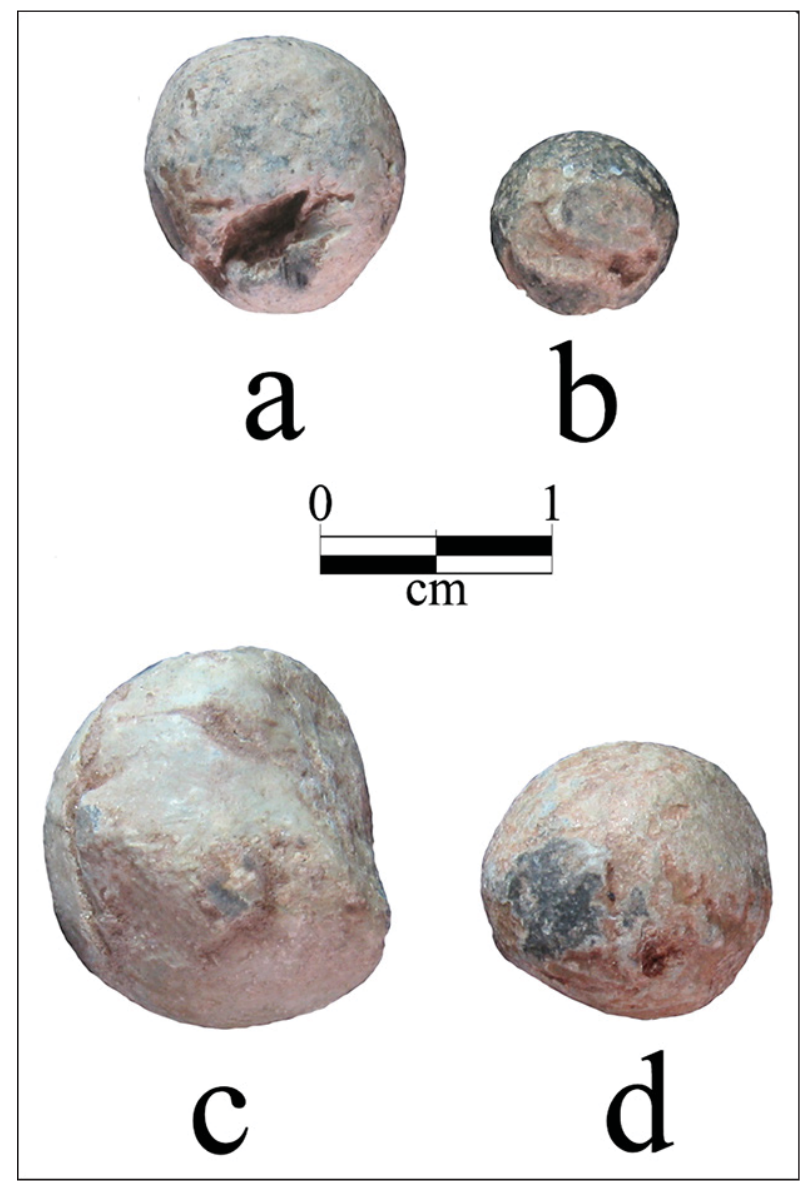

Figure 25. Lead shot in the Head collections from the Roseborough Lake site. 


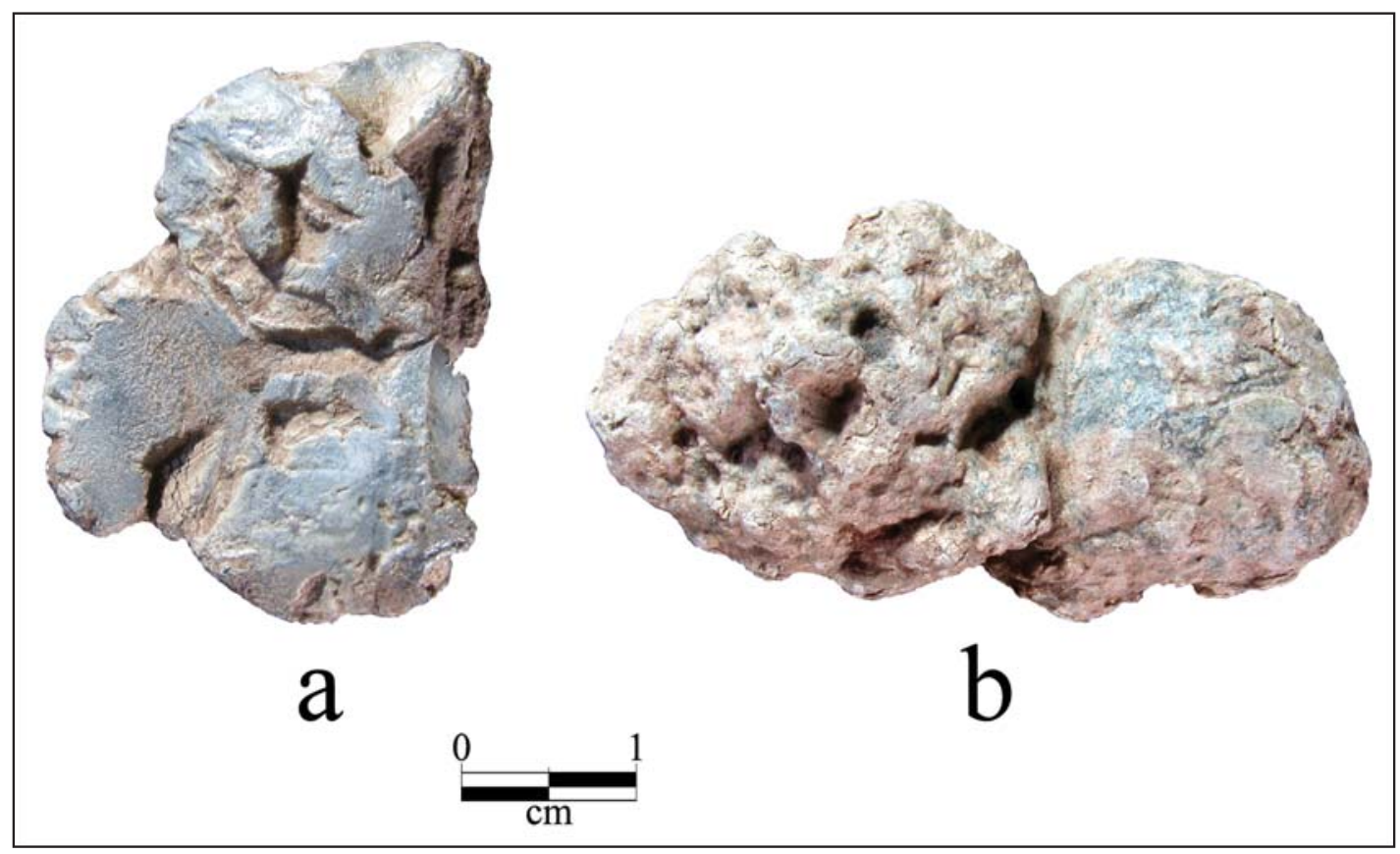

Figure 26. Lead sprue in the Head collection from the Roseborough Lake site.

\section{Animal Bones and Mussel Shell}

The animal bones in the Head collection have not been analyzed at the present time, but they are generally well-preserved. More than 970 pieces of animal bone are in the collection. No more than 10 mussel shell fragments were collected by Head from the disturbed surface of the Roseborough Lake site.

\section{Summary and Conclusions}

The Roseborough Lake site is an $18^{\text {th }}$ century Nasoni Caddo settlement and apparent French trading post situated on a natural levee landform of the Red River, not far upriver from the Hatchel (41BW3) and Eli Moores (41BW2) sites, important mound centers noted by the Teran entrada in 1691. Both of these sites were occupied in the $16^{\text {th }}$ and $17^{\text {th }}$ centuries by Nasoni Caddo peoples, but had been abandoned by the time the Nasoni settled the Roseborough Lake site, between ca. A.D. 1719-1778.

Archaeological investigations at the Roseborough Lake site began in the 1930s, but more intensive research was conducted by Miroir et al. (1973) beginning in the 1940s and by Gilmore (1986) in the mid1970s. This work uncovered evidence of an extensive Historic Nasoni Caddo occupation with structural features, midden deposits, and burials (likely in several cemeteries) at the southern part of the site, along with an artifact assemblage dominated by ancestral Caddo ceramic vessel sherds from fine ware, utility ware, and plain ware and chipped stone triangular arrow points and scraping tools. Also present in the Nasoni Caddo component were a wide array of European trade goods, including guns, gunflints, glass beads, tinklers, knives, and other artifacts. The age of these European goods at the Roseborough Lake site, as well as French and American archival documents, suggest that the French Nassonite post (Fort St. Louis de Kadohadacho) was established here in 1719 (Miroir et al. 1973:162-163).

In 1990 and 1991 the Lawrence Head family began collecting artifacts from the surface of the Historic Nasoni Caddo component at the Roseborough Lake site, after the site had been disturbed by Red River flooding and extensive land-leveling by the new property owners. The collection areas overlapped with the areas investigated earlier by Miroir et al. (1973) and Gilmore (1986), and a substantial assemblage of $18^{\text {th }}$ century Nasoni Caddo artifacts and European trade goods (mainly glass beads, lead 
balls and shot, and gunflints) were collected from several different parts of the site (see Figure 5), and retained by the Head's until 2016, when access to the collection was given for analysis, documentation, and publication purposes. The Head collection also contains early $19^{\text {th }}$ century artifacts associated with the 1827-1841 Collin McKinney plantation at the Roseborough Lake site, but they have yet to be documented or studied in any detail.

Ancestral Caddo ceramic vessel sherds $(\mathrm{n}=3650)$ were by far the most abundant artifact in the Head collection from the Roseborough Lake site, and their study has provided a detailed view of the character of an early to late $18^{\text {th }}$ century Nasoni Caddo ceramic assemblage. Furthermore, based on data from ceramic vessel sherds recovered in the platform mound excavations at the Hatchel site (41BW3), the nearby Eli Moores site (41BW2), and the Roseborough Lake site (see Figure 1), it is clear that there were significant differences in the character of ancestral Nasoni Caddo ceramics from the late $17^{\text {th }}$ century through the late $18^{\text {th }}$ century. To set the temporal context, Zone A at the Hatchel platform mound is the latest structure zone in the mound, and likely dates to around ca. A.D. 1690; the mound and site was visited by the Teran entrada in 1691, and the structures in Zone A were likely occupied at that time (Perttula 2015:1 and Figure 3a, 2017). The Eli Moores site likely dates to ca. A.D. 1690-early $18^{\text {th }}$ century (Perttula 2014b), and the Roseborough Lake sites postdates these Nasoni Caddo sites by at least one or two generations, and is estimated to have been occupied by the Nasoni Caddo from A.D. 17191778 (Miroir et al. 1973; Gilmore 1986).

One of the most notable differences between these assemblages is the considerable increase in the use of shell temper for ceramic vessel manufacture during the early-late $18^{\text {th }}$ century occupation at the Roseborough Lake site, from 5.7-8.3 percent at Eli Moores and Hatchel to 45.0 percent in the sherds in the Head collection at Roseborough Lake (Table 15). Higher percentages of shell-tempered ceramics have even been documented at the late $17^{\text {th }}$-A.D. 1730 component at the Cedar Grove site (3LA97) well downstream along the Red River from Roseborough Lake: 86 percent of the plain and utility ware sherds are from shell-tempered vessels and 38 percent of the fine ware sherds where temper was apparent are also from shell-tempered vessels (Schambach and Miller 1984:109).

Table 15. Comparisons between ceramic assemblages at the Roseborough Lake site (Head collection), Eli Moores site (41BW2), and Zone A at the Hatchel mound site (41BW3).*

\begin{tabular}{|c|c|c|c|}
\hline Decorative method & $\begin{array}{l}\text { Roseborough } \\
\text { Lake (41BW5) }\end{array}$ & 41BW2 & 41BW3 \\
\hline Percent shell-tempered & $45.0 \%$ & $5.7 \%$ & $8.3 \%$ \\
\hline \multicolumn{4}{|l|}{ Utility Ware } \\
\hline Appliqued & $0.8 \%$ & $6.3 \%$ & $6.0 \%$ \\
\hline Appliqued-Brushed & - & $0.1 \%$ & $0.9 \%$ \\
\hline Appliqued-Punctated & $0.1 \%$ & $0.1 \%$ & - \\
\hline Appliqued-Roughened & - & - & $0.5 \%$ \\
\hline Brushed & $6.0 \%$ & $8.6 \%$ & $8.8 \%$ \\
\hline Brushed-Appliqued & - & $1.2 \%$ & - \\
\hline Brushed-Incised & $1.0 \%$ & $0.2 \%$ & $6.0 \%$ \\
\hline Brushed-Punctated & $0.3 \%$ & $0.4 \%$ & $0.5 \%$ \\
\hline $\begin{array}{l}\text { Brushed-Punctated- } \\
\text { Appliqued }\end{array}$ & - & $0.1 \%$ & - \\
\hline $\begin{array}{l}\text { Brushed-Punctated- } \\
\text { Incised }\end{array}$ & - & $0.1 \%$ & - \\
\hline
\end{tabular}


Table 15. Comparisons between ceramic assemblages at the Roseborough Lake site (Head collection), Eli Moores site (41BW2), and Zone A at the Hatchel mound site (41BW3), cont.*

\begin{tabular}{|c|c|c|c|}
\hline Decorative method & $\begin{array}{l}\text { Roseborough } \\
\text { Lake (41BW5) }\end{array}$ & 41BW2 & 41BW3 \\
\hline Incised & $41.4 \%$ & $14.6 \%$ & $14.3 \%$ \\
\hline Incised-Appliqued & - & $1.1 \%$ & - \\
\hline Incised-Lip Notched & $0.1 \%$ & - & - \\
\hline Incised-Punctated & $0.4 \%$ & $0.5 \%$ & $1.8 \%$ \\
\hline $\begin{array}{l}\text { Incised-Punctated- } \\
\text { Appliqued }\end{array}$ & - & $0.2 \%$ & - \\
\hline Lip Notched & $0.2 \%$ & $0.1 \%$ & - \\
\hline Neck Banded & $0.5 \%$ & $1.0 \%$ & $3.2 \%$ \\
\hline Punctated & $6.6 \%$ & $3.8 \%$ & $5.1 \%$ \\
\hline Punctated-Lip Notched & $0.1 \%$ & - & \\
\hline Ridged & - & $0.4 \%$ & $0.5 \%$ \\
\hline Roughened & - & $0.2 \%$ & $0.9 \%$ \\
\hline Trailed (Foster) & $2.9 \%$ & $6.2 \%$ & $3.2 \%$ \\
\hline Trailed-Appliqued (Foster) & - & - & $0.5 \%$ \\
\hline \multicolumn{4}{|l|}{ Fine Ware } \\
\hline Engraved & $34.0 \%$ & $48.0 \%$ & $28.6 \%$ \\
\hline Engraved-Appliqued & - & $0.3 \%$ & - \\
\hline Engraved-Lip Notched & - & $0.2 \%$ & - \\
\hline Engraved-Red Slipped & $0.2 \%$ & $1.0 \%$ & $1.4 \%$ \\
\hline $\begin{array}{l}\text { Engraved-Red Slipped- } \\
\text { Lip Notched }\end{array}$ & - & $0.1 \%$ & - \\
\hline Engraved-Incised & $0.4 \%$ & - & $0.5 \%$ \\
\hline Excised Punctations & - & $0.1 \%$ & $1.8 \%$ \\
\hline Red Slipped & $2.2 \%$ & $2.0 \%$ & $4.6 \%$ \\
\hline Trailed (Keno) & $2.8 \%$ & $3.0 \%$ & $11.1 \%$ \\
\hline
\end{tabular}

*41BW2 data (Perttula 2014b); 41BW3 data (Perttula 2017)

In the utility wares, sherds from incised vessels (Ebarb Incised and Emory Punctated-Incised) came to document the Nasoni Caddo ceramic assemblages after ca. A.D. 1719, as utility wares with incised decorative elements at the Roseborough Lake site comprise 41.5 percent of the assemblage as a whole, compared to only 14.3-15.7 percent in the Hatchel and Eli Moores components (see Table 
15). Other utility wares are more common in pre-A.D. 1719 contexts, including appliqued sherds from Cass Appliqued vessels (6.5-7.4 percent in pre-A.D. 1719 contexts and 0.9 percent in post-A.D. 1719 contexts), brushed sherds from Karnack Brushed-Incised vessels (10.6-15.3 percent in pre-A.D. 1719 contexts and 7.3 percent in post-A.D. 1719 contexts), sherds from Nash Neck Banded vessels (1.0-3.2 percent in pre-A.D. 1719 contexts and only 0.5 percent in post-A.D. 1719 contexts), and McKinney Plain and Belcher Ridged vessel sherds are present only in pre-A.D. 1719 contexts (see Table 15). Foster Trailed-Incised vessel sherds are present in comparable percentages in each of the Nasoni Caddo components.

Two notable trends in the fine wares is the decreased occurrence of Keno Trailed vessel sherds and red-slipped vessel sherds from pre- to post-A.D. 1719 contexts, from 11.1 percent to 2.8 percent and 4.6 percent to 2.2 percent, respectively (see Table 15). Engraved sherds with a red slip also decrease from 1.4 percent to 0.2 percent through time in the assemblages. Among the engraved fine ware sherds, the highest proportions are in the Eli Moores assemblage, at 48.0 percent, but engraved fine ware sherds range from 28.6-34.0 percent in the Hatchel and Roseborough Lake sites, respectively, so fine wares remain relatively common in Nasoni Caddo ceramic traditions from pre-A.D. 1690 to post-A.D. 1719 times.

What is different through time in these Nasoni Caddo ceramic assemblages is in the specific fine ware types, other than Keno Trailed, that were being made and used from one component to another. In the Hatchel site fine wares, the best represented fine ware types are Barkman Engraved, Simms Engraved, and Belcher Engraved; at the Eli Moores site, the two most common fine ware types are Simms Engraved and Barkman Engraved; only two of 588 engraved sherds at the Eli Moores site are from Natchitoches Engraved vessels. Conversely, in the Head collection from the Roseborough Lake site, Natchitoches Engraved vessel sherds $(n=35)$ are most abundant, followed by Simms Engraved $(n=27)$. After A.D. 1719, Natchitoches Engraved vessels are well represented, but are virtually absent in pre-A.D. 1719 Nasoni Caddo contexts, while Simms Engraved (both grog-tempered and shell-tempered varieties) was common in both pre-A.D. 1719 and post-A.D. 1719 contexts in Nasoni Caddo ceramic assemblages. Caddo ceramic vessels in the ca. A.D. 1760-1790 component at the Indian Springs \#2 site (41BW512), a few miles upstream from Roseborough Lake, included a Natchitoches Engraved bowl, a Womack Engraved jar, a Simms Engraved carinated bowl, and an Emory Punctated-Incised jar (Perttula 2005:4344); none of the vessels were shell-tempered, however.

In summary, the ancestral Caddo artifacts in the Head collections from the Roseborough Lake site represent the material remains of a Nasoni Caddo occupation dating to the early to late $18^{\text {th }}$ century. The character of that occupation is best represented by the Caddo ceramic utility ware, fine ware, and plain ware assemblage, split between shell-tempered and grog-tempered vessels of the types Natchitoches Engraved, Simms Engraved, Keno Trailed, Hudson Engraved, Emory Punctated-Incised, Ebarb Incised, Karnack Brushed-Incised, Cass Appliqued, Foster Trailed-Incised, and Karnack Brushed-Incised. The Nasoni Caddo were also interacting and trading with Frenchmen at the Nassonite Post, and obtaining a variety of trade goods from French traders, among them guns and ornaments; the Nasoni Caddo living at the Roseborough Lake site were also participating in the burgeoning trade with Europeans in hides of deer and buffalo.

\section{Acknowledgments}

First, I want to thank Lawrence Head for permission to study the collections obtained from the Roseborough Lake site in the early 1990s, and for his wish that this collection be curated in perpetuity at the Texas Archeological Research Laboratory at the University of Texas; he also provided Figure 2 in this article. Next, thanks to Bo Nelson for making the arrangements to get the collections from Mr. Head, rebagging and reboxing the materials, and transporting the extensive collection to Austin. Finally, thanks to Lance Trask for preparing the figures and photographs in this article. 


\section{References Cited}

Avery, G.

2008 Seed Bead Color Patterns from Colonial Period Sites in Texas and Louisiana. Journal of Northeast Texas Archaeology 28:57-63.

Blaine, J. C. and R. K. Harris

1967 Guns. In "The Gilbert Site: A Norteno Focus Site in Northeastern Texas," edited by E. B. Jelks. Bulletin of the Texas Archeological Society 37:33-86.

Gilmore, K.

1986 French-Indian Interaction at an Early Eighteenth Century Post: The Roseborough Lake Site, Bowie County, Texas. Contributions in Archaeology 3. Institute of Applied Sciences, North Texas State University, Denton.

Gregory, H. F. and G. Avery

2007 American Indian Pottery from Historic Period Sites in North Louisiana. Journal of Northeast Texas Archaeology 26:33-76.

Hamilton, T. M.

1976 Firearms on the Frontier: Guns at Michilimackinac 1715-1781. Reports in Mackinac History and Archaeology No. 5. Mackinac Island State Park Commission and printed by Pendell Printing, Inc., Midland, Michigan.

1979 Guns, Gunflints, Ball and Shot. In Tunica Treasure, by J. P. Brain, pp. 206-216. Peabody Museum of Archaeology and Ethnology, Harvard University, Cambridge, Massachusetts and the Peabody Museum of Salem, Salem, Massachusetts.

Kenmotsu, N. A.

1990 Gunflints: A Study. Historical Archaeology 24(2):92-124.

Kidd, K. E. and M. A. Kidd

1970 A Classification System for Glass beads for the Use of Field Archaeologists. Occasional Papers in Archaeology and History No. 1, pp. 45-89. National Historic Sites Service, National and Historic Parks Branch, Department of Indian Affairs and Northern Development, Ottawa, Ontario.

Miroir, M. E., R. K. Harris, J. C. Blaine, and J. McVay

1973 Bernard de la Harpe and the Nassonite Post. Bulletin of the Texas Archeological Society 44:113-167.

Perttula, T. K.

2005 The Indian Springs \#2 Site (41BW512): A Late $18^{\text {th }}$ Century Kadohadacho Settlement in Northeastern Texas. Journal of Northeast Texas Archaeology 22:39-52.

2014a The Joe M. Smith Collection from the Roseborough Lake Site (41BW5), Bowie County, Texas. Journal of Northeast Texas Archaeology 47:17-20.

2014b Material Culture Remains. In The Eli Moores Site, a 17 th to early $18^{\text {th }}$ Century Caddo Site on the Red River, Bowie County, Texas, edited by T. K. Perttula, pp. 23-61. Special Publication No. 31. Friends of Northeast Texas Archaeology, Austin and Pittsburg.

2015 Caddo Ceramic Vessels from the Hatchel Site (41BW3) on the Red River in Bowie County, Texas. Special Publication No. 39. Friends of Northeast Texas Archaeology, Austin and Pittsburg.

2017 Analysis of the Hatchel Site (41BW3) Platform Mound Ceramic Vessel, Vessel Section, Sherds, Pipes, and Other Clay Artifacts. Special Publication No. 45, Vol. I-II. Friends of Northeast Texas Archaeology, Austin and Pittsburg. MS in preparation. 
Schambach, F. F. and J. E. Miller

1984 A Description and Analysis of the Ceramics. In Cedar Grove: An Interdisciplinary Investigation of a Late Caddo Farmstead in the Red River Valley, edited by N. L. Trubowitz, pp. 109-170. Research Series No. 23. Arkansas Archeological Survey, Fayetteville.

Story, D. A., B. Barber, E. Barber, E. Cobb, H. Cobb, R. Coleman, K. Gilmore, R. K. Harris, and N. Hoffrichter 1967 Pottery Vessels. In "The Gilbert Site: A Norteno Focus Site in Northeastern Texas," edited by E. B. Jelks. Bulletin of the Texas Archeological Society 37:112-187.

Suhm, D. A. and E. B. Jelks (editors)

1962 Handbook of Texas Archeology: Type Descriptions. Special Publication No. 1, Texas Archeological Society, and Bulletin No. 4, Texas Memorial Museum, Austin. 